\title{
COVID-19: Pulmonary and Extra Pulmonary Manifestations
}

\author{
Islam H. Elrobaa ${ }^{1 *}$ and Karl J. New ${ }^{2 *}$ \\ ${ }^{1}$ Emergency Medicine Specialist in Hamad Medical Corporation, Qatar and Lecturer in Clinical Education Department, \\ College of Medicine, Qatar University, Doha, Qatar, ${ }^{2}$ Clinical Physiology, School of Health, Sport, and Professional Practice, \\ Faculty of Life Science and Education, University of South Wales, Treforest, United Kingdom
}

\section{OPEN ACCESS}

Edited by:

Monica Catarina Botelho, Instituto Nacional de Saúde Doutor Ricardo Jorge (INSA), Portugal

Reviewed by:

Jian Wu,

Zhejiang University, China Tarek A. Ahmad,

Bibliotheca Alexandrina, Egypt

*Correspondence:

Islam H. Elrobaa

dr_islamelrobaa@yahoo.com

Karl J. New

karl.new@southwales.ac.uk

Specialty section:

This article was submitted to Infectious Diseases-Surveillance,

Prevention and Treatment,

a section of the journal

Frontiers in Public Health

Received: 20 May 2021

Accepted: 30 July 2021

Published: 28 September 2021

Citation:

Elrobaa IH and New KJ (2021) COVID-19: Pulmonary and Extra

Pulmonary Manifestations.

Front. Public Health 9:711616.

doi: 10.3389/fpubh.2021.711616
Introduction: The coronavirus disease-2019 (COVID-19) pandemic has been the most significant event in 2020, with $\sim 86.8$ million cases and 1.88 million deaths worldwide. It is a highly infectious disease, wherein the virus (severe acute respiratory syndrome coronavirus 2) rapidly multiplies and spreads to all parts of the body. Therefore, COVID-19 is not only respiratory disease but also a multisystem disease. Many people, including physicians, incorrectly believe that the disease affects only the respiratory tract. In this study, we aimed to describe COVID-19 manifestations and the underlying pathophysiology to provide the readers with a better understanding of this disease to achieve good management and to control the spread of this disease.

Methods: Secondary data were obtained from PubMed, Google Scholar, and Scopus databases. The keywords used for the search were as follows: COVID-19, COVID-19 pulmonary manifestations, COVID-19 extra pulmonary manifestations, and pathophysiology of COVID-19. We collected secondary data from systemic reviews, metaanalyses, case series, and case reports in the form of public data that was published on websites of the government, medical corporations, medical peer-reviewed journals, and medical academies, all of which were indexed in PubMed, Google Scholar, or Scopus. Our questions were as follows: Is COVID-19 a respiratory disease only? and What are the extrapulmonary manifestations of COVID-19?

Results: From our data, we found that a patient with COVID-19 may be either asymptomatic or symptomatic. Symptomatic cases may have either pulmonary or extrapulmonary manifestations. Pulmonary manifestations occur as mild, moderate, or severe cases. In mild and moderate cases, extrapulmonary manifestations such as gastroenteritis, fever, or vomiting may present alone. Some of these cases may be missed for diagnosis, and the patient may receive symptomatic treatment without a COVID-19 diagnosis, leading to increased spread of the infection. Extrapulmonary manifestations may occur in severe and critical cases as complications of severe infections (high viral overload) or the cytokine storm, such as in acute kidney injury (AKI), heart failure (HF), and venous thromboembolic (VTE) manifestation.

Conclusion: COVID-19 is not a respiratory disease alone; rather, it is a multisystem disease. Pulmonary and extrapulmonary manifestations should be considered for early diagnosis and to control the spread of the infection.

\footnotetext{
Keywords: COVID-19, manifestations, pulmonary, extra pulmonary, infection control
} 


\section{INTRODUCTION}

The novel coronavirus disease-2019 (COVID-19) is currently one of the most rapidly spreading diseases worldwide. The causative pathogen, severe acute respiratory syndrome coronavirus 2 (SARS-CoV-2), is an animal and a human pathogen. The disease originated in Wuhan City, China, and then spread to the rest of the world (1). The chief features of the disease are as follows: (1) a high viral-multiplying capacity, (2) an extensive spread leading to a high prevalence, (3) being a newly discovered novel disease, there are no standardized treatment regimens until recently, and (4) a high mortality rate in some communities (2).

The disease may present as mild, moderate, or severe in terms of the severity of presentation. The mild disease may be characterized by symptoms such as body aches, coughs, or mild fever, while in its moderate form the disease may present with mild pneumonia along with other symptoms. The severe form of the disease presence may be characterized by severe pneumonia and hypoxia. Critical cases with significant hypoxia and organ failure may need admission to the intensive care unit (ICU) and mechanical ventilation support (3-5). Besides the symptomatic cases, asymptomatic cases have also been reported (5-7).

Due to the rapid spread of the disease worldwide, many countries were forced to close their borders and impose internal lockdowns to curb the spread. With an incubation period of 14 days (2), the symptoms can be detected $\sim 4-5$ days after exposure (4). Currently, the mortality rate due to the disease is $\sim 2-5 \%$ according to the community, but it may reach as high as $7 \%$ as observed in Italy (8-10).

Severe and critical forms can be easily identified based on the presence of SARS symptoms (2) and confirmed with chest radiography (5). The mild and moderate forms may have non-specific symptoms such as fever, gastroenteritis, vomiting, dysgeusia (loss of taste), and headache with no or mild respiratory symptoms (11). Knowledge of these extrapulmonary manifestations can help in detecting the mild and moderate forms, which can aid in early diagnosis, and rapid quarantining can prevent community spread.

In this review, we have discussed COVID-19 as both a respiratory tract infection and a multisystem disease. We also discuss the underlying pathophysiology of the disease and its manifestations, which can serve as a basis for good management, treatment, and infection control. In addition, the results of this study will provide an understanding of the COVID-19, enabling our medical colleagues to improve the quality of health care management.

\section{METHODS}

We collected data on COVID-19 from the databases PubMed, Google Scholar, and Scopus. We used the following keywords in our search: COVID-19 pulmonary manifestations, extrapulmonary manifestations of COVID-19, COVID-19 clinical presentations, the pathophysiology of COVID-19, and management of COVID-19. We collected secondary data from systemic reviews, meta-analyses, case series, and case reports from public data published on websites of the government, medical corporations, medical peer-reviewed journals, and medical academies, which were all indexed on PubMed, Google Scholar, or Scopus. We collected data about the clinical manifestations, pathophysiological effects, and the management of the COVID-19 disease. Specific questions were raised to understand the presentations and manifestations of COVID-19. Does COVID-19 present exclusively as pulmonary manifestations only? What are the extrapulmonary presentations of COVID-19? Complete understanding of COVID-19 in terms of its pathophysiology and manifestations leads to good planning regarding the control and prevention of the spread of the disease.

\section{RESULTS}

We found two main types of COVID-19 manifestations: pulmonary and extrapulmonary manifestations. Pulmonary manifestations are most well-known because these cases are critical, difficult to manage, and have poor outcomes. Extrapulmonary manifestations of COVID-19 are common in moderate and mild cases and may also occur together with pulmonary manifestations or in severe infection cases, with multiple complications. Many physicians may not be sufficiently aware of these extrapulmonary manifestations; therefore, such cases may be missed to be identified and can cause the spread of COVID-19 to a greater degree in the community. Asymptomatic cases of COVID-19 have also been reported. To understand COVID-19 manifestations, we should understand the underlying mechanisms and pathophysiology of the disease. Risk factors that can determine COVID-19 progression in the patient should be considered. The pathophysiology of COVID-19 may help in understanding how to treat and manage this disease. Our results explain the pathophysiology of COVID-19, risk factors that determine the COVID-19 effect and spread, pulmonary and extrapulmonary manifestations of COVID-19, and the management of COVID-19. Refer to Figures 1, 2.

\subsection{Pathophysiology of COVID-19}

Understanding disease pathophysiology is crucial to understand the clinical presentation. The coronavirus $(\mathrm{CoV})$ is classified according to its genotypic form into alpha $\alpha$, beta $\beta$, gamma $\gamma$, and omega o (12). $\alpha$ and $\beta$ CoVs are the human infecting forms. SARS-CoV1 and SARS-CoV2 are members of $\beta$ CoVs, but SARS-CoV2 has a spike of glycoprotein with a high affinity to the angiotensin-converting enzyme-2 (ACE2) receptors (13, 14). ACE2 receptors are located in the pulmonary alveolar cell type II, small intestine, colon, gallbladder, testes, brain stem, esophagus, heart, and blood vessels in the basal layer of the epidermis (15-17). This highlights the relation between the disease symptoms and ACE2 receptor distributions in the human body $(7,18,19)$.

When blood pressure decreases in the renal juxtaglomerular apparatus, it releases renin into the bloodstream. Renin acts on angiotensin (from the liver) and converts it to angiotensin-I. Angiotensin-1, in turn, is converted into angiotensin-2 by the action of the angiotensinconverting enzyme (ACE1). Angiotensin-2 has a 


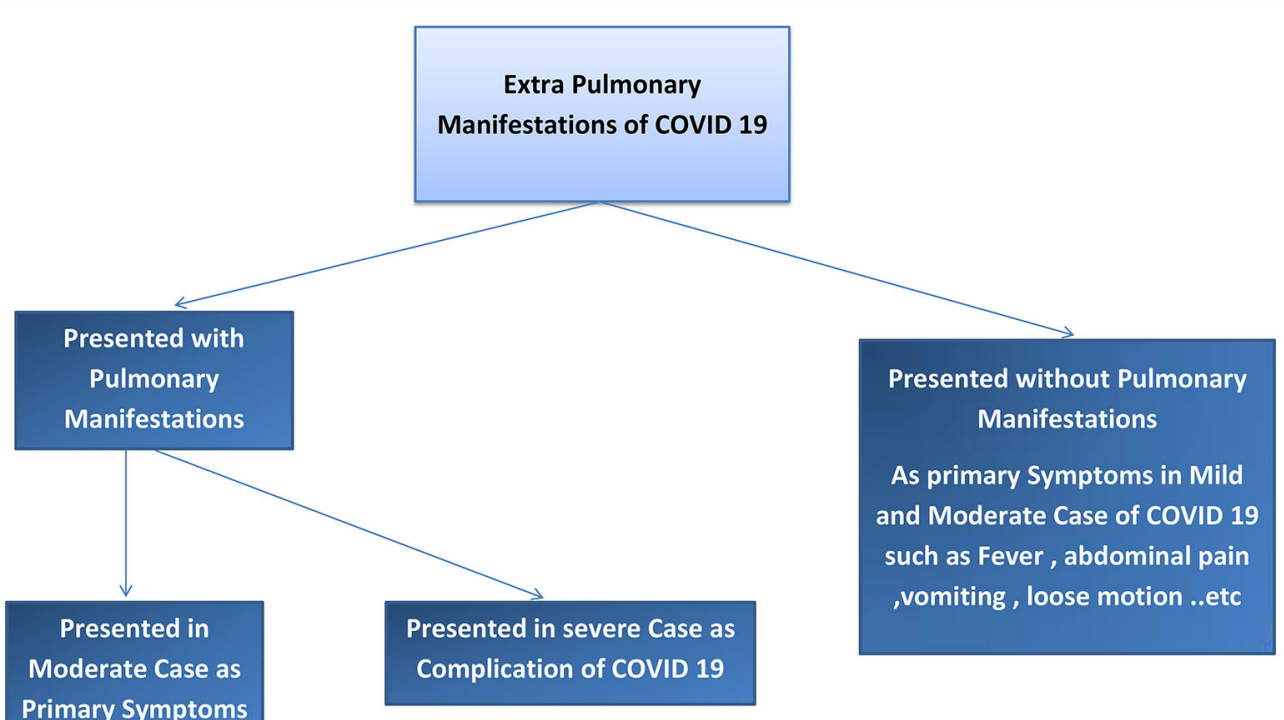

FIGURE 1 | Diagram to explain the presentation of extrapulmonary manifestations of COVID-19.

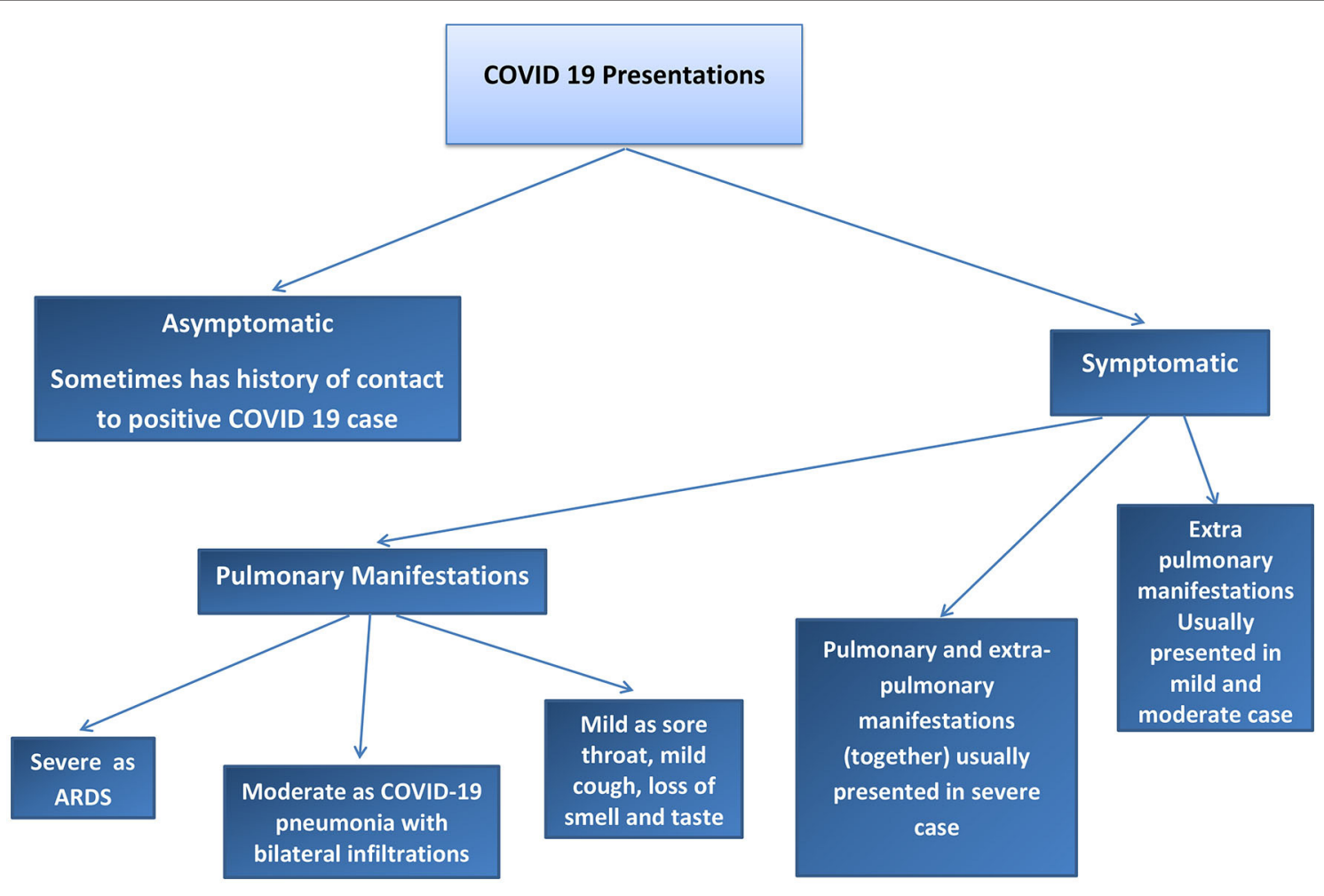

FIGURE 2 | Diagram to explain the COVID-19 presentations in Health care provider centres.

vasoconstrictor effect that increases blood pressure by increasing renal perfusion and stimulating aldosterone release (20).

Angiotensin-converting enzyme-2 has a contrary effect of ACE1, thereby reducing serum levels of angiotensin-2 (21). ACE2 binds to its receptor and catalyzes the hydrolysis of angiotensin
II to angiotensin. This reduces blood pressure, heart rate, and alveolar surface tension, which is important for treating acute respiratory distress syndrome (ARDS) (22). ACE2 is the entry point for SARS CoV-2 into cells through endocytosis. The virus, along with the enzyme, is then translocated into the cell endosome (23). 
Coronavirus disease-2019 spreads through physical contact and inhalation of infected droplets or air. It then invades the airway epithelium, where the viral load is increased by replication. Pyroptosis occurs by the leaking of the virus from the upper respiratory tract vasculature into the bloodstream, which then travels to other target organs that have ACE2 receptors. This process induces a T-cell-mediated inflammatory response, which releases interleukins and cytokines (24). This cytokine storm may lead to the development of ARDS (25).

The leaked SARS-CoV-2 then travels to other organs with ACE2 receptors, leading to extrapulmonary features, such as gastroenteritis (small intestine); insomnia, dysgeusia, and headache (brainstem, cerebral cortex, and hypothalamus, respectively), high blood pressure, and tachycardia (heart and blood vessels, respectively), and some skin infections (basal epidermis). ACE2 receptors may be present in the retina and other eye tissues, leading to conjunctivitis when infected $(26,27)$. A host of other immune and inflammatory responses are also triggered by the infection $(15,28-33)$.

Many factors can determine the severity of COVID-19, including viral load, genetic factors, presence of comorbidities, age, sex, use of immune-suppressive agents, and immunity (34). Some authors believe that genetic factors also play a role in the severity of COVID-19 because the ACE2 receptor gene has multiple polymorphisms, which means that there are multiple variations in the relationship between SARS-CoV-2 and ACE2 receptor according to ethnicity and gene form. This difference in a relationship can explain the severity of the disease in a specific race than others (35).

People with comorbidities such as diabetes mellitus, hypertension, chronic obstructive pulmonary disease (COPD), chronic lung disease, chronic kidney disease, cancer, and low immunity may have a greater affinity for severe infections and serious complications of COVID-19 (7). Many comorbidities lead to defects in ACE2 expression (36). For example, patients with essential hypertension may have defects in the ACE1/ACE2 balance, which leads to severe symptoms of COVID-19 in that patient. Some studies have suggested that patients with comorbidities have a more severe form of COVID-19, and studies that included a high proportion of patients with ARDS as a complication of COVID-19 showed that the patients had comorbidities before contracting the infection (37).

Some studies have shown that elderly people have a greater disease severity than young people (38). Most pulmonary complications, such as ARDS, are more frequent in the elderly with COVID-19, and multiple organ failures also occur with a higher frequency in elderly people with COVID-19 (39). Immunity and comorbidity are predisposing factors that affect the complications of COVID-19 in the elderly (40). Some studies have suggested that ACE2 expression is higher in the lungs of old people than in the lungs of people of other ages (41). In addition, the mortality rate is higher in the elderly group (42).

Many studies have suggested that men are affected more by COVID-19 than women because the ACE2 expression is higher in men. Furthermore, the testes may also express ACE2, and
ACE2 levels in the plasma are higher in men than in women. Some lifestyle factors associated with COVID-19 were smoking, alcohol consumption, and other factors that are more common in men than in women. Other studies have shown that critical care admission was higher in men with COVID-19 than in women with COVID-19. The mortality rate in men with COVID-19 was also higher than that in women with COVID-19 $(43,44)$.

Obesity plays a role in COVID-19 severity because ACE2 expression is higher in adipose tissue (45). Obese people have a higher risk of respiratory failure and are more frequent candidates for mechanical ventilation (46). Many COVID-19 critical cases have a higher body mass index (47). The mortality rate with COVID-19 is higher in obese patients because of respiratory failure and heart failure [HF; (48)]. Obese people may also have more comorbidities such as hypertension and diabetes mellitus, factors that affect COVID-19 severity (49). In essential hypertension, there is a defect in the ACE/ACE2 balance, and this is more common in obese patients (50).

\subsubsection{Cytokine Storm}

The physiological immunological reaction by the innate immune system can cause an excessive release of proinflammatory cytokines such as interleukins and cytokines (51). The cause may be cytomegalovirus and streptococcal A infection or a skin graft. The excessive release of cytokines and interleukins may lead to a huge inflammatory process in the body that induces multiorgan failure and ARDS (52).

Immunity plays a major role in determining the severity and reactions of COVID-19 (53). Some authors have mentioned that people with low immunity are at a greater risk for severe respiratory distress and multiple organ failure due to COVID-19 (54). In contrast, many studies reported that a high immune reaction can predispose a cytokine storm that leads to acute respiratory distress and multiple organ failure by immune-mediated reactions against the body tissue and organs. Acute kidney injury (AKI), ARDS, myocarditis, skin manifestations, ocular manifestations, and neurological manifestations of COVID-19 may occur due to the cytokine storm (55). Immunosuppressive agents should not be stopped in patients who are being treated with these agents. Many studies have suggested that patients who use cytokine inhibitors do not exhibit the severe features of COVID-19 because of the inhibitory action on the hyperinflammatory condition of COVID-19 (56). Refer to Figure 3.

\subsection{Pulmonary Manifestation of COVID-19}

Pulmonary manifestations in COVID-19 may be mild, moderate, and severe (57). Mild cases such as upper respiratory tract infection (URTI), cough, or sore throat can progress to moderate and severe degrees (58). The moderate type of pulmonary presentation of COVID-19 could be pneumonia and fever (59). The COVID-19 pneumonia type has been reported in some cases as silent pneumonia with fever or silent pneumonia in a sick patient (60). We found cases of silent hypoxia as a result of silent COVID-19 pneumonia (60). The severe manifestation of COVID-19 is ARDS (61). There are two pathological mechanisms to explain ARDS in COVID-19 patients. The first 


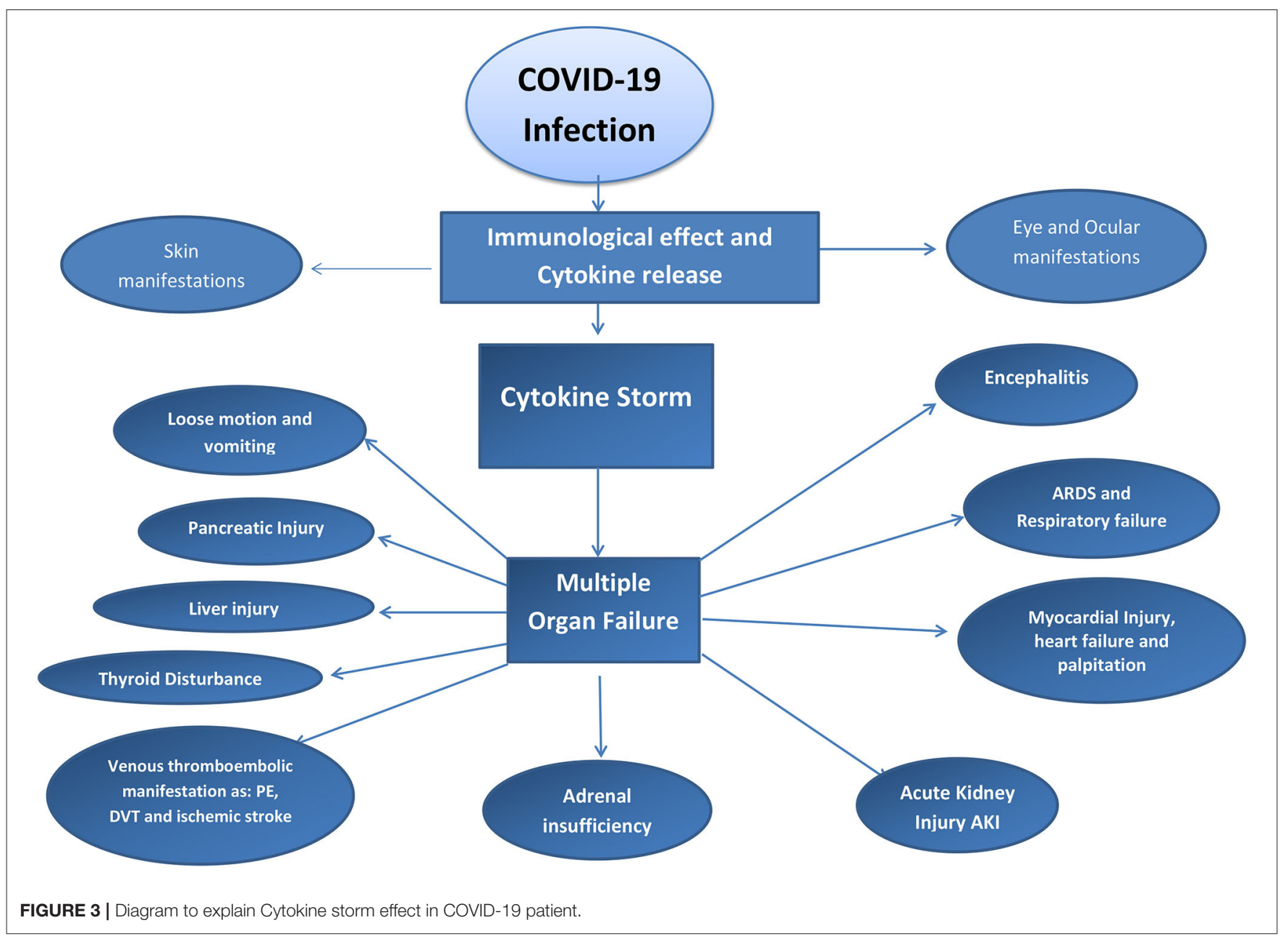

mechanism discusses that the ACE2 receptor is located in pneumocyte type II (62). ACE2 and pneumocyte type 2 play a role in producing the pulmonary surfactant $(62,63)$. ACE2 can improve the blood flow in the alveolar cell, which improves the alveolar cell function as a pneumocyte type 2, which produces the pulmonary surfactant $(62,63)$. The ACE2 receptor is the host of SARS-COV-2 to the human cell. So when SARS-CoV-2 binds to ACE2 receptors, it leads to destruction and damage in the alveolar cells and decreases the pulmonary surfactant that leads to an increase in the surface tension of the lung and predisposition to ARDS $(62,63)$. The second suggested mechanism for ARDS in COVID-19 patients is the cytokine storm. Cytokine storm is a hyperimmune response to specific triggers such as viral infections that lead to a large release of proinflammatory cytokines, such as cytokines and interleukins, leading to an excessive inflammatory response that leads to multiple organ failure and destruction in alveolar cells with ARDS. Multiple factors can determine the severity of the pulmonary manifestations such as viral overload, genetic roles and ethnicity, presence of comorbidities, age, and sex (64). The most common causes of mortality in COVID 19 are ARDS, severe COVID-19 pneumonia, and multiple organ failure (65). Refer to Table 1.

\subsubsection{Discussion Point}

Pulmonary manifestations in COVID-19 may present as URTI and cough progressing to ARDS or as a sudden stack of ARD due to silent pneumonia and hypoxia. Sometimes, a bilateral ground-glass appearance can be seen on a CT scan for asymptomatic cases of COVID-19. The most common features of the chest radiographic manifestations of COVID-19 are bilateral infiltration, bilateral ground-glass appearance, bilateral pneumonia (patches), and pleural effusion. However, the American College of Radiology recommends not to perform a CT scan to diagnose COVID-19 in asymptomatic patients (Refer to below section COVID-19 Manifestations and Diagnosis).

\subsection{Cardiovascular Manifestations of COVID-19}

Angiotensin-converting enzyme receptors are located in the cardiac tissue, and during a SARS-CoV-2 attack, they may cause cardiac tissue degeneration because the ACE receptors are affected by SARS-CoV-2. Many cardiac manifestations have been reported in COVID-19 cases such as arrhythmias, hypertension, palpitations, myocarditis, myocardial injuries, cardiomyopathies, and HF (66). Two mechanisms are leading to the response of 
TABLE 1 | Pulmonary manifestations of COVID 19.

\begin{tabular}{|c|c|c|c|c|}
\hline Manifestations & References & Patients & $\begin{array}{l}\text { The affected } \\
\text { patients }\end{array}$ & Incidence \\
\hline URTI & $\begin{array}{l}\text { Liu, Ping et al. "Epidemiological and clinical } \\
\text { features in patients with coronavirus disease }\end{array}$ & 209 & 21 & $10 \%$ \\
\hline $\begin{array}{l}\text { Pneumonia } \\
\text { and Fever }\end{array}$ & $\begin{array}{l}2019 \text { outside of Wuhan, China: Special focus in } \\
\text { asymptomatic patients." PLoS neglected tropical } \\
\text { diseases vol. 15,3 e0009248. } 10 \text { Mar. 2021, } \\
\text { doi: } 10.1371 \text { journal.pntd.0009248 }\end{array}$ & & 180 & $86.1 \%$ \\
\hline \multirow{4}{*}{$\begin{array}{l}\text { Silent } \\
\text { Hypoxia }\end{array}$} & $\begin{array}{l}\text { Teo, Jason. "Early Detection of Silent Hypoxia in } \\
\text { Covid-19 Pneumonia Using Smartphone Pulse }\end{array}$ & -- & --- & $\begin{array}{l}\text { *Seen frequently in our } \\
\text { Practice }\end{array}$ \\
\hline & Oximetry." Journal of medical systems vol. 44,8 & & & in HMC, Qatar \\
\hline & $\begin{array}{l}\text { 134. } 19 \text { Jun. } \\
\text { 2020, doi: } 10.1007 / \mathrm{s} 10916-020-01587-6\end{array}$ & & & \\
\hline & $\begin{array}{l}\text { Wilkerson, R Gentry et al. "Silent hypoxia: A } \\
\text { harbinger of clinical deterioration in patients with } \\
\text { COVID-19." The American journal of emergency } \\
\text { medicine vol. } 38,10 \text { (2020): } \\
\text { 2243.e5-2243.e6. doi: } 10.1016 / \text { j.ajem.2020.05.044 }\end{array}$ & Case report & Case report & \\
\hline ARDS & $\begin{array}{l}\text { Tzotzos, Susan J et al. "Incidence of ARDS and } \\
\text { outcomes in hospitalized patients with COVID-19: } \\
\text { a global literature survey." Critical care (London, } \\
\text { England) vol. } 24,1516.21 \text { Aug. } 2020 \text {, } \\
\text { doi: } 10.1186 / s 13054-020-03240-7\end{array}$ & 2212 & 738 & $33 \%$ \\
\hline
\end{tabular}

cardiac manifestations of COVID-19. The first is the effect of SARS-CoV-2 on the ACE2 receptors in the cardiac tissue. The second mechanism is the cytokine storm that can cause HF and other cardiac manifestations (67). Viral overload sometimes determines the severity of the extrapulmonary manifestations, such as cardiovascular symptoms of COVID-19 (68). Some of the medications that were used to treat COVID-19-induced arrhythmias included hydroxychloroquine and chloroquine (69). Some clinical studies have shown elevated levels of cardiac enzymes such as troponin T in ICU COVID-19 patients (70). Elevation in pro BNP levels was also reported in ICU patients. Some retrospective studies showed diffuse ST elevations in COVID-19 patients, and urgent coronary angioplasty showed no coronary obstruction (71). However, myocardial infarction (MI) was reported in the ICU and hospitalized COVID-19 patients (72). Some authors mentioned arrhythmias in COVID19 patients admitted to the ICU; most of these arrhythmias were paroxysmal atrial fibrillation (73). One of the studies recorded sudden cardiac death in 19 hospitalized patients; the patients had an HF with a low ejection fraction. Another study mentioned Takotsubo cardiomyopathy as one of the COVID-19 cardiovascular complications (74). Hypertension and palpitations were reported in many COVID-19 patients in their first visit to the health care provider. Hypoxia was counted as the cause of the cardiac arrhythmias and type 2 MIs in COVID19 patients. MI in COVID-19 patients may be presented as type I, which results in the rupture of plaque thrombus, leading to occlusion of the coronary artery, or may be a result of severe hypoxia that leads to an ischaemic type II MI (75). Refer to Table 2.

\subsubsection{Discussion Point}

The cardiovascular manifestation of COVID-19 may present initial symptoms, such as palpations, new diagnoses of hypertension, or chest pains, and may also present as late symptoms or complications in the ICU or hospitalized COVID19 patient. The cardiovascular manifestations were reported in young, middle-aged, and old age patients with COVID-19.

COVID-19 may induce the following: (1) hypoxia by ARDS that leads to decreased oxygen supply to the heart muscle, leading to myocardial degradation and increased troponin $\mathrm{T}$ levels that lead to type II MI, (2) vascular injury due to the effect of SARS-CoV-2 on endothelial cells that lead to platelet aggregation and vascular plaques or thrombi that on detachment block the coronary blood vessels and can induce ischaemic MI. (3) SARS-CoV-2 has direct effect on ACE2 receptors on the myocardium that can cause myocarditis. (4) The cytokine storm may lead to cardiomyopathy and HF. Over-disease stress may lead to Takotsubo cardiomyopathy. Many viral overloads and genetic factors play a role in determining the cardiovascular complications and their severity in COVID-19 patients.

\subsection{Gastroenterology Manifestations}

The COVID-19 patient may present with loose motion, anorexia, nausea, vomiting, abdominal pain, epigastric pain, liver injury, and pancreatic injury. Elevated levels of liver enzymes including ALT, AST, and alkaline phosphatase have been reported (76). In addition, high levels of lipase and amylase were reported in some patients with COVID-19 (77). The mechanism of Gastrointestinal Tract (GIT) manifestations in COVID-19 depends on three factors: viral overload, and the direct effect of SARS-CoV-2 on the ACE2 receptors on the epithelium of the esophagus or mucus layer in the stomach and small intestine (17). ACE2 is also expressed in the liver tissue (78). The cytokine storm is considered the third factor that determines GIT symptoms, and it can induce gastroenteritis symptoms, liver injury, and pancreatic injury $(79,80)$. One retrospective study in China showed that $75 \%$ of COVID-19 patients had diarrhea 
TABLE 2 | Cardiovascular manifestations of COVID 19.

\begin{tabular}{|c|c|c|c|c|}
\hline $\begin{array}{l}\text { Cardiovascular } \\
\text { manifestations }\end{array}$ & References & Patients & $\begin{array}{l}\text { Affected } \\
\text { patients }\end{array}$ & Incidence \\
\hline Arrhythmia & $\begin{array}{l}\text { Wang, Dawei et al. "Clinical Characteristics of } 138 \\
\text { Hospitalized Patients With } 2019 \text { Novel } \\
\text { Coronavirus-Infected Pneumonia in Wuhan, China." JAMA } \\
\text { vol. 323,11 (2020): 1061-1069. doi: 10.1001/jama.2020.1585 }\end{array}$ & 138 & 23 & $16 \%$ \\
\hline $\begin{array}{l}\text { Cardiac injury } \\
\text { and } \\
\text { high troponin } \mathrm{T}\end{array}$ & $\begin{array}{l}\text { Huang, Chaolin et al. "Clinical features of patients } \\
\text { infected with } 2019 \text { novel coronavirus in Wuhan, China." } \\
\text { Lancet (London, England) vol. 395,10223 (2020): 497-506. } \\
\text { doi: } 10.1016 / \text { S0140-6736(20)30183-5 }\end{array}$ & 41 & 5 & $12 \%$ \\
\hline AF & $\begin{array}{l}\text { Inciardi, Riccardo M et al. "Characteristics and outcomes } \\
\text { of patients hospitalized for COVID-19 and cardiac disease } \\
\text { in Northern Italy." European heart journal vol. } 41,19 \text { (2020): } \\
\text { 1821-1829. doi: } 10.1093 / \text { eurheartj/ehaa388 }\end{array}$ & 99 & $\begin{array}{l}19 \text { [ known } \\
\text { cardiac } \\
\text { disease ] }\end{array}$ & $19 \%$ \\
\hline $\begin{array}{l}\text { Sudden cardiac } \\
\text { death }\end{array}$ & $\begin{array}{l}\text { Baldi, Enrico et al. "COVID-19 kills at home: the close } \\
\text { relationship between the epidemic and the increase of } \\
\text { out-of-hospital cardiac arrests." European heart journal } \\
\text { vol. } 41,32 \text { ( } 2020): 3045-3054 \text {. } \\
\text { doi: } 10.1093 / \text { eurheartj/ehaa508 }\end{array}$ & $\begin{array}{l}321 \text { in } 2019 \\
\text { And } 490 \text { in } \\
2020\end{array}$ & 169 & $34 \%$ \\
\hline $\begin{array}{l}\text { Takotsubo } \\
\text { cardiomyopathy }\end{array}$ & $\begin{array}{l}\text { Bottiroli M, De Caria D, Belli O, et al. Takotsubo syndrome } \\
\text { as a complication in a critically ill COVID-19 patient. ESC } \\
\text { Heart Fail. 2020. https://doi.org/10.1002/ehf2.12912. }\end{array}$ & Case report & & \\
\hline Hypertension & $\begin{array}{l}\text { Wang, Dawei et al. "Clinical Characteristics of } 138 \\
\text { Hospitalized Patients With } 2019 \text { Novel } \\
\text { Coronavirus-Infected Pneumonia in Wuhan, China." JAMA } \\
\text { vol. } 323,11 \text { (2020): 1061-1069. doi: 10.1001/jama.2020.1585 }\end{array}$ & 138 & 43 & $31.2 \%$ \\
\hline Type II MI & $\begin{array}{l}\text { Shi S, Qin M, Shen B, et al. Association of cardiac injury } \\
\text { with mortality in hospitalized patients with COVID-19 in } \\
\text { Wuhan, China. JAMA Cardiol 2020; https://doi.org/10. } \\
\text { 1001/jamacardio.2020.0950 }\end{array}$ & 416 & 82 & $19.7 \%$ \\
\hline
\end{tabular}

(81). Also, same study reported abdominal pain in COVID-19 patient presentation (81). On other hand, liver injury with an elevation in liver enzyme reported in COVID 19 patients who admitted in the ICU (82). Some authors have mentioned acute pancreatitis as a cytokine storm complication (83). Some drugs, such as antiviral drugs, are considered hepatotoxic and induce liver injury in COVID-19 patients (84). The comorbidities, for example, diabetes mellitus and lifestyle factors including alcohol consumption, have a role in determining the symptoms and degree of COVID-19 cases (85). Some studies discovered the SARS-CoV-2 in the feces of COVID-19 patients (86). However, another study reported the presence of SARS-CoV-2 in the epithelium of the esophagus and mucus of the stomach in COVID-19 patients by endoscopy. However, endoscopy is safe in cases of GIT bleeding in COVID-19 cases (87). Refer to Table 3.

\subsubsection{Discussion Point}

GIT symptoms in COVID-19 patients are one of the primary and initial symptoms that are frequently seen in mild to moderate cases of COVID-19. The causes of GIT symptoms are as follows: viral overload, SARS-CoV-2 effect on ACE2 expression in GIT, and the cytokine storm. COVID-19 patients present with late symptoms or complications. Diarrhea or loose motion is the most frequent primary symptom in COVID-19 patients. However, late complications that occur in severe infection or critical cases may include GIT symptoms such as liver injury, pancreatic injury, and GIT bleeding. GIT endoscope is safe for use in GIT bleeding management. Epigastric pain and abdominal pain were considered as primary manifestations of COVID-19 and also as COVID-19-related GIT manifestations due to gastritis and abdominal colic.

\subsection{Renal Manifestations}

The most important renal manifestation of COVID-19 is AKI. Some studies have shown an increased risk of mortality in COVID-19 patients who have AKI to a greater extent than the other patients who have normal kidney function $(88,89)$. Haematuria and proteinuria were reported as renal complications of COVID-19 (90). Some authors have suggested the direct effect of SARS-CoV-2 on the kidney because ACE2 is expressed in the kidney tissue (91). The ACE2 receptor is found in renal tubules and may be affected by SARS-CoV-2 (92). The cytokine storm affects kidney function and may induce acute renal failure (89). Increased blood levels of creatinine and blood urea nitrogen (BUN) are considered to increase the risk of hospital death in COVID 19 patients in the ICU (90). A postmortem study showed the histopathological feature of acute renal tubular necrosis in patients who died due to COVID-19 (78). The viral load may also play a role in the renal manifestations of COVID-19 (93). Some studies have shown renal function deterioration in patients with severe pneumonia (94). Patients with chronic diseases, such as DM and chronic kidney disease, 
TABLE 3 | GIT manifestations.

\begin{tabular}{|c|c|c|c|c|}
\hline GIT manifestations & References & Total patients & $\begin{array}{l}\text { Affected } \\
\text { patients }\end{array}$ & Incidence \\
\hline Loose motion & $\begin{array}{l}\text { Wan Y et al., 2020. Enteric involvement in hospitalised } \\
\text { patients with COVID-19 outside Wuhan. Lancet } \\
\text { Gastroenterol Hepatol 5: 534-535 }\end{array}$ & 230 & 49 & $23 \%$ \\
\hline \multirow[t]{2}{*}{ Vomiting, nausea and anorexia } & $\begin{array}{l}\text { Wu, Yi-Chi et al. "The outbreak of COVID-19: An } \\
\text { overview." Journal of the Chinese Medical Association : } \\
\text { JCMA vol. } 83,3 \text { (2020): } \\
\text { 217-220. doi: } 10.1097 / J C M A .0000000000000270\end{array}$ & 80 & 1 & $1.25 \%$ \\
\hline & $\begin{array}{l}\text { Wang, Dawei et al. "Clinical Characteristics of } 138 \\
\text { Hospitalized Patients With } 2019 \text { Novel } \\
\text { Coronavirus-Infected Pneumonia in Wuhan, China." JAMA } \\
\text { vol. 323,11 (2020): 1061-1069. doi: 10.1001/jama.2020.1585 }\end{array}$ & 138 & $\begin{array}{l}\text { Vomiting in } 5 \\
\text { patients } \\
\text { Nausea in } 14 \\
\text { patients }\end{array}$ & $\begin{array}{l}3.6 \% \\
10.1 \%\end{array}$ \\
\hline Abdominal pain & $\begin{array}{l}\text { Wang, Dawei et al. "Clinical Characteristics of } 138 \\
\text { Hospitalized Patients With } 2019 \text { Novel } \\
\text { Coronavirus-Infected Pneumonia in Wuhan, China." JAMA } \\
\text { vol. 323,11 (2020): 1061-1069. doi: 10.1001/jama.2020.1585 }\end{array}$ & 138 & 3 & $2.2 \%$ \\
\hline Epigastric pain & $\begin{array}{l}\text { Han, Chaoqun et al. "Digestive Symptoms in COVID-19 } \\
\text { Patients With Mild Disease Severity: Clinical Presentation, } \\
\text { Stool Viral RNA Testing, and Outcomes." The American } \\
\text { journal of gastroenterology vol. 115,6 (2020): 916-923. } \\
\text { doi: 10.14309/ajg.0000000000000664 }\end{array}$ & 206 & 9 & $\begin{array}{l}4.4 \% \\
\text { *seen } \\
\text { frequently in } \\
\text { our Practice in } \\
\text { HMC, Qatar }\end{array}$ \\
\hline Pancreatic Injury & $\begin{array}{l}\text { Liu F, Long X, Zhang B, Zhang W, Chen X, Zhang Z, } 2020 . \\
\text { ACE2 expression in pancreas may cause pancreatic } \\
\text { damage after SARS-CoV-2 infection. Clin Gastroenterol } \\
\text { Hepatol 18: 2128-2130.e2. }\end{array}$ & 121 & $\begin{array}{l}\text { Amylase } \\
\text { increased in } \\
13 \text { patients } \\
\text { Lipase } \\
\text { increased in } \\
12 \text { patients }\end{array}$ & $\begin{array}{l}10.74 \% \\
9.92 \%\end{array}$ \\
\hline Liver injury & $\begin{array}{l}\text { Fang D, Jingdong MA, Guan J, Wang M, Song J, Tian D, } \\
\text { Peiyuan LI, 2020. Manifestations of digestive system in } \\
\text { hospitalized patients with novel coronavirus pneumonia in } \\
\text { Wuhan, China: a single-center, descriptive study. Chin J } \\
\text { Dig 40: E005 }\end{array}$ & 99 & 43 & $43 \%$ \\
\hline GIT bleeding & $\begin{array}{l}\text { Cavaliere, Kimberly et al. "Management of upper GI } \\
\text { bleeding in patients with COVID-19 pneumonia." } \\
\text { Gastrointestinal endoscopy vol. 92,2 (2020): 454-455. } \\
\text { doi: } 10.1016 / \text { j.gie.2020.04.028 }\end{array}$ & $\begin{array}{l}\text { Case series of } 6 \\
\text { patients with } \\
\text { COVID-19 } \\
\text { pneumonia and } \\
\text { upper GI bleeding }\end{array}$ & & \\
\hline
\end{tabular}

TABLE 4 | Acute renal manifestations in COVID 19.

\begin{tabular}{|c|c|c|c|c|}
\hline Renal manifestation & References & $\begin{array}{l}\text { Number of } \\
\text { total patients }\end{array}$ & $\begin{array}{l}\text { The affected } \\
\text { patients }\end{array}$ & The incidence \\
\hline Haematuria & $\begin{array}{l}\text { Pei, Guangchang et al. "Renal Involvement and } \\
\text { Early Prognosis in Patients with COVID-19 } \\
\text { Pneumonia." Journal of the American Society } \\
\text { of Nephrology : JASN vol. } 31,6 \text { (2020): } \\
\text { 1157-1165. doi: 10.1681/ASN.2020030276 }\end{array}$ & 333 & $\begin{array}{l}\text { Haematuria } \\
139 / 333\end{array}$ & $(41.7 \%)$ \\
\hline proteinuria & & & $\begin{array}{l}\text { Proteinuria } \\
219 / 333\end{array}$ & $65.8 \%$ \\
\hline Acute kidney injury & & & $35 / 333$ & $10.5 \%$ \\
\hline Acute tubular necrosis[Arteriosclerosis ] & $\begin{array}{l}\text { Su, Hua et al. "Renal histopathological analysis } \\
\text { of } 26 \text { postmortem findings of patients with } \\
\text { COVID-19 in China." Kidney international vol. } \\
98,1(2020): 219-227 . \\
\text { doi: } 10.1016 / \text { j.kint.2020.04.003 }\end{array}$ & $\begin{array}{l}26 \text { postmortem } \\
\text { findings of } \\
\text { patients with } \\
\text { COVID-19 in } \\
\text { China }\end{array}$ & & \\
\hline Hyperkalemia & $\begin{array}{l}\text { Malieckal, Deepa A et al. "Electrolyte } \\
\text { abnormalities in patients hospitalized with } \\
\text { COVID-19." Clinical kidney journal vol. } 14,6 \\
\text { 1704-1707. } 16 \text { Mar. } 2021 \text {, } \\
\text { doi: } 10.1093 / \text { ckj/sfab060 }\end{array}$ & 10348 & 638 & $6.6 \%$ \\
\hline
\end{tabular}


TABLE 5 | Neurological manifestations of COVID 19.

\begin{tabular}{|c|c|c|c|c|c|}
\hline $\begin{array}{l}\text { Type of } \\
\text { Neurological } \\
\text { Disease }\end{array}$ & Manifestations & References & $\begin{array}{l}\text { Number of } \\
\text { total patients }\end{array}$ & $\begin{array}{l}\text { The affected } \\
\text { patients }\end{array}$ & The Incidence \\
\hline \multirow[t]{10}{*}{$\begin{array}{l}\text { Central } \\
\text { nervous } \\
\text { system }\end{array}$} & Headache & $\begin{array}{l}\text { Mao, Ling et al. "Neurologic Manifestations of } \\
\text { Hospitalized Patients With Coronavirus Disease } 2019 \text { in } \\
\text { Wuhan, China." JAMA neurology vol. } 77,6(2020) \text { : } \\
683-690 \text {. doi: 10.1001/jamaneurol.2020.1127 }\end{array}$ & 214 & 28 & $13.1 \%$ \\
\hline & Dizziness & & & 36 & $16.8 \%$ \\
\hline & Seizures & & & 2 & $2 \%$ \\
\hline & Cerebral haemorrhage & $\begin{array}{l}\text { Craen, Alexandra et al. "Novel Coronavirus Disease } \\
2019 \text { and Subarachnoid Hemorrhage: A Case Report." } \\
\text { Cureus vol. 12,4 e7846. } 27 \text { Apr. 2020, } \\
\text { doi: } 10.7759 / \text { cureus.7846 }\end{array}$ & Case report & Case report & \\
\hline & $\begin{array}{l}\text { Acute cerebrovascular } \\
\text { disease }\end{array}$ & $\begin{array}{l}\text { Mao, Ling et al. "Neurologic Manifestations of } \\
\text { Hospitalized Patients With Coronavirus Disease } 2019 \text { in } \\
\text { Wuhan, China." JAMA neurology vol. } 77,6 \text { (2020): } \\
683-690 \text {. doi: 10.1001/jamaneurol.2020.1127 }\end{array}$ & 214 & 6 & $2.8 \%$ \\
\hline & Ischemic stroke & $\begin{array}{l}\text { Tan, Y. K., Goh, C., Leow, A., Tambyah, P. A., Ang, A., } \\
\text { Yap, E. S., Tu, T. M., Sharma, V. K., Yeo, L., Chan, B., \& } \\
\text { Tan, B. (2020). COVID-19 and ischemic stroke: a } \\
\text { systematic review and meta-summary of the literature. } \\
\text { Journal of thrombosis and thrombolysis, 50(3), 587-595. } \\
\text { https://doi.org/10.1007/s11239-020-02228-y }\end{array}$ & 362 & 9 & $2.5 \%$ \\
\hline & Insomnia & $\begin{array}{l}\text { Kokou-Kpolou, Cyrille Kossigan et al. "Insomnia during } \\
\text { COVID-19 pandemic and lockdown: Prevalence, } \\
\text { severity, and associated risk factors in French } \\
\text { population." Psychiatry research vol. } 290(2020) \text { : } \\
\text { 113128. doi: 10.1016/j.psychres.2020.113128 }\end{array}$ & 556 & & $18.2 \%$ \\
\hline & & $\begin{array}{l}\text { Huang, Yeen, and Ning Zhao. "Generalized anxiety } \\
\text { disorder, depressive symptoms and sleep quality during } \\
\text { COVID-19 outbreak in China: a web-based } \\
\text { cross-sectional survey." Psychiatry research vol. } 288 \\
\text { (2020): 112954. doi: 10.1016/j.psychres.2020.112954 }\end{array}$ & 7236 & 1317 & $18.2 \%$ \\
\hline & $\begin{array}{l}\text { cerebral venous } \\
\text { thrombosis }\end{array}$ & $\begin{array}{l}\text { Garaci, Francesco et al. "Venous cerebral thrombosis in } \\
\text { COVID-19 patient." Journal of the neurological sciences } \\
\text { vol. } 414 \text { (2020): 116871. doi: 10.1016/j.jns.2020.116871 }\end{array}$ & Case report & & \\
\hline & Ataxia & $\begin{array}{l}\text { Mao, Ling et al. "Neurologic Manifestations of } \\
\text { Hospitalized Patients With Coronavirus Disease } 2019 \text { in } \\
\text { Wuhan, China." JAMA neurology vol. } 77,6(2020) \text { : } \\
683-690 \text {. doi: 10.1001/jamaneurol.2020.1127 }\end{array}$ & 214 & 1 & $0.5 \%$ \\
\hline \multirow[t]{8}{*}{$\begin{array}{l}\text { Peripheral } \\
\text { neurological } \\
\text { manifestation }\end{array}$} & Gillian bare syndrome & $\begin{array}{l}\text { Sedaghat Z, Karimi N. Guillain Barre syndrome } \\
\text { associated with COVID-19 infection: A case report. J } \\
\text { Clin Neurosci. } 2020 \text { Jun;76:233-235. } \\
\text { doi: 10.1016/j.jocn.2020.04.062 Epub } 2020 \text { Apr 15. PMID: } \\
\text { 32312628; PMCID: PMC7158817 }\end{array}$ & Case report & & \\
\hline & $\begin{array}{l}\text { ophthalmoplegia and } \\
\text { polyneuritis }\end{array}$ & $\begin{array}{l}\text { Guidon AC, Amato AA. COVID-19 and neuromuscular } \\
\text { disorders. Neurology. 2020; 94(22):959-69 }\end{array}$ & Review & & \\
\hline & & $\begin{array}{l}\text { Mao, Ling et al. "Neurologic Manifestations of } \\
\text { Hospitalized Patients With Coronavirus Disease } 2019 \text { in } \\
\text { Wuhan, China." JAMA neurology vol. } 77,6(2020) \text { : } \\
\text { 683-690. doi: 10.1001/jamaneurol.2020.1127 }\end{array}$ & 214 & $\begin{array}{l}\text { Loss Taste in } \\
12 \text { patients }\end{array}$ & $5.6 \%$ \\
\hline & & & & $\begin{array}{l}\text { Loss Smell in } \\
11 \text { patients }\end{array}$ & $5.1 \%$ \\
\hline & & & & $\begin{array}{l}\text { Vision Defect } \\
\text { in } 3 \text { patients }\end{array}$ & $1.4 \%$ \\
\hline & & & & $\begin{array}{l}\text { Nerve pain in } 5 \\
\text { patients }\end{array}$ & $2.3 \%$ \\
\hline & & & & $\begin{array}{l}\text { Skeletal } \\
\text { muscle injury } \\
\text { in } 23 \text { patients }\end{array}$ & $10.7 \%$ \\
\hline & $\begin{array}{l}\text { Acute myelitis and } \\
\text { Hypotonia }\end{array}$ & $\begin{array}{l}\text { AlKetbi, Reem et al. "Acute myelitis as a neurological } \\
\text { complication of Covid-19: A case report and MRI } \\
\text { findings." Radiology case reports vol. 15,9 1591-1595. } 6 \\
\text { Jun. 2020, doi: 10.1016/j.radcr.2020.06.001 }\end{array}$ & & Case report & \\
\hline
\end{tabular}


may have a higher risk of kidney function deterioration with COVID-19 along with a high mortality rate (95). Hyperkalaemia may occur in hospitalized patients (96). Refer to Table 4.

\subsubsection{Discussion Point}

Acute kidney injury is considered one of the COVID-19 manifestations in severe and critical cases. It may also occur as a complication of COVID-19 pneumonia. Viral overload and comorbidity may play a role in determining the severity of AKI in COVID-19. In high viral overload, the ACE2 receptor has a direct effect from SARS-CoV-2, leading to AKI, and a cytokine storm that results from high infection may lead to AKI. Comorbidities, such as diabetic mellitus and chronic kidney disease, are predisposing factors for AKI in COVID-19 patients or acute on top of chronic kidney disease in COVID-19 patients. Hyperkalaemia is a complication of acute renal failure or AKI. Proteinuria and haematuria are considered manifestations of AKI.

\subsection{The Neurological Manifestations}

The neurological manifestations of COVID-19 may be central or peripheral symptoms (97). The central nervous symptom manifestations may be headaches, dizziness, ischaemic stroke, intracranial hemorrhage, encephalitis, seizures, loss of smell (dysgeusia), or insomnia (98). Peripheral nervous manifestations may include neuropraxia, ophthalmoplegia, ataxia, loss of tendon reflex, Miller Fisher syndrome, and Guillain-Barre syndrome (99). Acute transverse myelitis with hypotonia has been reported in some patients with COVID-19 (100). The mechanism of neurological manifestations of COVID-19 may be because the SARS-CoV-2 exerts a direct effect on ACE2 receptors that are distributed in brain tissue (101). Some authors suggested that SARS-CoV-2 could be ascending by olfactory nerve axons to the brain and thalamus (101). The autopsy specimen showed brain edema and degeneration in the nerve ending by a post-mortem study in the dead body of COVID-19 (98). SARS-CoV 2 has a hypercoagulopathy effect, which can explain the ischaemic stroke incident in COVID-19 patients (102). Some studies reported high fever with a disturbed consciousness level in some of the COVID19 patients, and cerebrospinal fluid analysis showed the presence of SARS-CoV-2. The patients were diagnosed with COVID19 and viral encephalitis (103). Seizure disorders have been previously reported in hospitalized COVID-19 patients without any history of epilepsy. Retrospective studies of hospitalized patients reported headache and dizziness in COVID-19 patients $(99,104)$. Cerebral hemorrhage occurs in some COVID-19 patients in the ICU (105). Some retrospective studies reported one patient with cerebral venous thrombosis and another with cerebral hemorrhage (106). Insomnia was also reported in some COVID-19 patients even after negative PCR results (107). Early neurological symptoms of mild COVID-19 patients may involve loss of smell, headache, and dizziness. Some cases reported about Guillain-Barre syndrome in a patient with COVID-19 also reported Miller Fisher syndrome $(108,109)$. Some retrospective studies showed peripheral neurological symptoms in COVID-19 patients with ophthalmoplegia and polyneuritis (110). Ataxia has been reported in COVID-19 patients (111). Acute myelitis with hypotonia and loss of tendon reflex are also seen (112). Refer to Table 5.

\subsubsection{Discussion Point}

The neurological manifestations of COVID-19 may include primary symptoms such as headache, dizziness, or loss of smell, or late complications such as cerebral hemorrhage and seizures. Neurological disorders may occur as complications of vascular thromboembolic disorder (VTE), causing brain ischaemia and stroke. The mechanism of nervous system defects in COVID19 patients is as follows: (1) The direct effect of SARS-CoV-2 on ACE2 receptors in the brain and nerve; some authors mention that SARS-CoV-2 can ascend from the olfactory nerve from the nasal cavity to the brain thalamus, (2) COVID-19 hypoxia may have an effect on brain tissue and could lead to brain oedema, (3) the cytokine storm may have an effect on the central and peripheral nervous systems, (4) the VTE effect of COVID-19 may lead to brain ischaemia and stroke. Many psychosis cases were reported in COVID-19 patients. Stroke and cerebral hemorrhage were reported in COVID-19 patients and acute myelitis with hypotonia in a patient with COVID-19. Gillian-Barre syndrome was also reported in COVID-19 patients. The effect of COVID19 on the peripheral nervous system may be determined by the degree of infection as a viral load and the severity of the case that can cause nervous system complications, as well as the effect of the virus on the nervous tissue or the complication of hypoxia and thromboembolic effect that causes nerve ischaemia. Genetic factors and comorbidities may have a role in the onset of nervous system manifestations.

\subsection{Psychiatric Manifestations}

Coronavirus disease-2019 has two categories of psychological manifestations (113). The first is psychiatric symptoms as a result of isolation and quarantine, and this type is frequent and showed depression, anxiety, sleeping disorders, eating disorders, somatizations, and phobias. The second category is the psychiatric disorder as a result of the effect of COVID19 itself (SARS-CoV-2 in the brain tissue). This type may be rare but was reported in a case series study for some patients with COVID-19 who developed psychosis in Spain (114). One observational study conducted among patients in isolation reported depression and suicidal ideation in some of them. Isolated and quarantine people need psychometric support during the isolation period and after isolation follow-up (115, 116). Refer to Table 6.

\subsubsection{Discussion Point}

The psychiatric manifestation of COVID-19 may be the result of the direct effect of SARS-CoV-2 on ACE2 receptors in the brain, which may manifest as psychosis, lack of sleep, insomnia, and anxiety. The presentation of psychiatric manifestations of COVID-19 as a primary symptom may infrequently be reported and seen in practice. The other type of psychiatric manifestation of COVID-19 resulted from secondary causes, such as isolation- and quarantine-related depression. Depression was reported in people both in quarantine and in some health care providers who manage COVID-19 patients. 
TABLE 6 | Psycahtric manifestations of COVID 19.

\begin{tabular}{|c|c|c|c|c|}
\hline Manifestation & References & study sample & $\begin{array}{l}\text { Affected } \\
\text { patients / people }\end{array}$ & Incidence \\
\hline $\begin{array}{l}\text { Psycahtric } \\
\text { symptoms as result }\end{array}$ & $\begin{array}{l}\text { Zhang, Jie et al. "The differential psychological } \\
\text { distress of populations affected by the }\end{array}$ & 57 & Depression Mild 18 & $31.6 \%$ \\
\hline $\begin{array}{l}\text { of isolation and } \\
\text { quarantine }\end{array}$ & $\begin{array}{l}\text { COVID-19 pandemic." Brain, behavior, and } \\
\text { immunity vol. } 87 \text { (2020): 49-50. }\end{array}$ & & Moderate 7 & $12.3 \%$ \\
\hline $\begin{array}{l}\text { Such as : } \\
\text { depression, }\end{array}$ & doi: 10.1016/j.bbi.2020.04.031 & & Severe 11 & $19.3 \%$ \\
\hline anxiety, & & & $\begin{array}{l}\text { Anxiety : Mild } 14 \\
\text { Moderate } 4 \\
\text { Severe } 8\end{array}$ & $\begin{array}{l}36.8 \% \\
26.7 \% \\
32.0 \%\end{array}$ \\
\hline sleeping disorders, & $\begin{array}{l}\text { Huang, Yeen, and Ning Zhao. "Generalized } \\
\text { anxiety disorder, depressive symptoms and } \\
\text { sleep quality during COVID-19 outbreak in } \\
\text { China: a web-based cross-sectional survey." } \\
\text { Psychiatry research vol. } 288 \text { (2020): } 112954 \text {. } \\
\text { doi: } 10.1016 / \text { j.psychres.2020.112954 }\end{array}$ & 7236 & 1317 & $18.2 \%$ \\
\hline eating disorders, & $\begin{array}{l}\text { Fernández-Aranda, Fernando et al. "COVID-19 } \\
\text { and implications for eating disorders." } \\
\text { European eating disorders review : the journal } \\
\text { of the Eating Disorders Association vol. } 28,3 \\
\text { (2020): } 239-245 . \text { doi: } 10.1002 / \text { erv.2738 }\end{array}$ & 32 & About 12 & $37.5 \%$ \\
\hline $\begin{array}{l}\text { Psychosis after } \\
\text { COVID } 19 \text { infection }\end{array}$ & $\begin{array}{l}\text { Rentero, D., Juanes, A., Losada, C. P., Álvarez, } \\
\text { S., Parra, A., Santana, V., Martí, I., \& Urricelqui, } \\
\text { J. (2020). New-onset psychosis in COVID-19 } \\
\text { pandemic: a case series in Madrid. Psychiatry } \\
\text { research, 290, 113097. https://doi.org/10.1016/ } \\
\text { j.psychres.2020.113097 }\end{array}$ & a case series & & \\
\hline suicidal ideation & $\begin{array}{l}\text { Czeisler, Mark É et al. "Mental Health, } \\
\text { Substance Use, and Suicidal Ideation During } \\
\text { the COVID-19 Pandemic - United States, June } \\
\text { 24-30, 2020." MMWR. Morbidity and mortality } \\
\text { weekly report vol. } 69,32 \text { 1049-1057. } 14 \text { Aug. } \\
\text { 2020, doi: } 10.15585 / \mathrm{mm} \text { wr.mm6932a1 }\end{array}$ & 5,470 & About 585 & $10.7 \%$ \\
\hline
\end{tabular}

Suicidal ideation was reported in patients in quarantine and isolation. Therefore, psychiatric support and follow-up may be required for people in isolation even in health care providers for COVID-19.

\subsection{Skin and Dermatological Manifestations of COVID-19}

Some authors mention the basal layer of the skin as the location of ACE2 receptors in the human body (117). Two pathophysiological mechanisms are underlying the cutaneous manifestations of COVID-19. The first is the direct effect of SARS-CoV-2 on ACE2 receptors in the basal layer of the skin, and the second mechanism may be complicated by the effects of drugs that are used to treat COVID-19, such as skin side effects due to azithromycin.

The cutaneous manifestations of COVID-19 may appear as erythema maculopapular redness, skin rash, and erythema. Some of the quarantine patients experienced skin erythema after a few days of quarantine. One study showed that COVID-19 patients presented with skin rash and erythema. Skin manifestations of COVID-19 may present before respiratory symptoms (118-123). Refer to Table 7.

\subsubsection{Discussion Point}

Skin manifestations of COVID-19 are reported as primary manifestations of COVID-19, also reported as late manifestations in patients in isolation and quarantine. The pathophysiological process may be the primary effect of SARS-CoV-2 on ACE2 in the basal layer of the skin, or secondary to the cytokine storm effect, or drug reaction used in COVID-19 management. Genetic factors may have a role in the appearance of the dermatological feature of COVID-19. The dermatological manifestations of COVID-19 are reported in mild and moderate cases of COVID-19.

\subsection{Ocular Manifestations}

The ocular manifestations of COVID-19 may occur through the direct effect of SARS-CoV-2, which is transmitted by droplet infection to the cornea and conjunctiva. The virus present in the droplets binds with ACE2 receptors located in the conjunctiva and cornea. SARS-CoV-2 may reach the eyes through systematic circulation according to the viral load. Some case reports showed ocular manifestation in COVID-19 as a burning eye sensation with redness. In addition, foreign body sensation and conjunctivitis were reported in COVID-19 cases. Some studies have recommended the use of Goggles to protect the eyes as a 
TABLE 7 | Skin manifestations of COVID 19.

\begin{tabular}{|c|c|c|c|c|}
\hline Manifestations & References & Sample size & $\begin{array}{l}\text { Affected } \\
\text { patients }\end{array}$ & Incidence \\
\hline \multirow[t]{4}{*}{$\begin{array}{l}\text { Macular popular } \\
\text { rash, skin rash and } \\
\text { Erythema }\end{array}$} & $\begin{array}{l}\text { Sachdeva M, Gianotti R, Shah M, Bradanini L, } \\
\text { Tosi D, Veraldi S, Ziv M, Leshem E, Dodiuk-Gad } \\
\text { RP, 2020. Cutaneous manifestations of } \\
\text { CoVID-19: report of three cases and a review } \\
\text { of literature. J Dermatol Sci } 98: 75-81\end{array}$ & \multicolumn{2}{|l|}{3 case report } & $\begin{array}{l}\text { I agree with the result I have } \\
\text { seen COVID } 19 \text { with cutaneous } \\
\text { manifestations in my practice in } \\
\text { field hospital FHOIA, HMC, } \\
\text { Qatar. }\end{array}$ \\
\hline & $\begin{array}{l}\text { Joob B, Wiwanitkit V, 2020. COVID-19 can } \\
\text { present with a rash and be mistaken for } \\
\text { dengue. J Am Acad Dermatol 82: e177. }\end{array}$ & \multicolumn{3}{|l|}{ Case report } \\
\hline & $\begin{array}{l}\text { Recalcati S. Cutaneous manifestations in } \\
\text { COVID-19: a first perspective. J Eur Acad } \\
\text { Dermatol Venereol. 2020;34(5):e212-3. }\end{array}$ & 88 & 18 & $20.4 \%$ \\
\hline & $\begin{array}{l}\text { Tammaro A, Adebanjo GAR, Parisella FR, } \\
\text { Pezzuto A, Rello J. Cutaneous manifestations } \\
\text { in COVID-19: the experiences of Barcelona and } \\
\text { Rome. J Eur Acad Dermatol Venereol. } \\
2020 ; 34(7): \text { 306-7 }\end{array}$ & 130 & 2 & $1.5 \%$ \\
\hline
\end{tabular}

TABLE 8 | Ocular manifestations of COVID 19.

\begin{tabular}{|c|c|c|c|c|}
\hline Manifestations & Reference & $\begin{array}{l}\text { The sample } \\
\text { size }\end{array}$ & $\begin{array}{l}\text { Affected } \\
\text { patients }\end{array}$ & Incidence \\
\hline \multirow{3}{*}{$\begin{array}{l}\text { Eye redness, conjunctivitis, } \\
\text { foreign body sensation and } \\
\text { burning eye sensation }\end{array}$} & $\begin{array}{l}\text { Zhang X, Chen X, Chen L, Deng C, Zou X, Liu } \\
\text { W, Yu H, Chen B, Sun X, 2020. The evidence of } \\
\text { SARS-CoV-2 infection on ocular surface. Ocul } \\
\text { Surf 18: } 360-362 \text {. }\end{array}$ & $\begin{array}{l}72 \text { confirmed } \\
\text { COVID } 19 \text { by } \\
\text { laboratory } \\
\text { diagnosis }\end{array}$ & 2 of 72 & About $2.78 \%$ \\
\hline & $\begin{array}{l}\text { Chen, Liwen et al. "Ocular manifestations and } \\
\text { clinical characteristics of } 535 \text { cases of } \\
\text { CoVID-19 in Wuhan, China: a cross-sectional } \\
\text { study." Acta ophthalmologica vol. } 98,8 \text { (2020): } \\
\text { e951-e959. doi: } 10.1111 \text { aos. } 14472\end{array}$ & 535 & $\begin{array}{l}27 \\
4 \text { patient has } \\
\text { conjunctivitis } \\
\text { as initial } \\
\text { symptoms }\end{array}$ & $\begin{array}{l}5 \% \\
0.7 \% \text { of total patient and } 14.8 \% \\
\text { of patient with ocular symptoms }\end{array}$ \\
\hline & $\begin{array}{l}\text { Wu P, Duan F, Luo C, Liu Q, Qu X, Liang L, Wu } \\
\text { K, 2020. Characteristics of ocular findings of } \\
\text { patients with coronavirus disease } 2019 \\
\text { (COVID-19) in hubei province, China. JAMA } \\
\text { Ophthalmol 138: } 575-578 \text {. }\end{array}$ & 38 & 12 & $31.5 \%$ \\
\hline
\end{tabular}

site of COVID-19 transmission. Some studies have mentioned conjunctivitis as an early symptom of COVID-19 (26, 27, 124128). Refer to Table 8.

\subsubsection{Discussion Point}

There are two ways for SARS-CoV-2 to reach the eye tissue. In the first method, droplet infection reaches the eye tissue by direct contact, and in the second method, it reaches through blood circulation, which occurs according to the viral overload. The cytokine storm may have an effect on eye manifestations. Eye manifestations are reported as primary manifestations of COVID-19 and may occur as late manifestations.

\subsection{Endocrinology Manifestations of COVID-19}

Some observational studies have shown abnormalities in thyroid function in COVID-19 patients. COVID-19 is a cause of ketosis in non-diabetes patients and may also create a high risk for diabetic keto acidosis (DKA) in diabetes patients. One study reported ketosis in a COVID-19 patient without any hyperglycaemia, vomiting, or fever. In addition, the pancreatic injury was reported in 19 cases, and amylase and lipase levels were elevated. The mechanism of endocrine manifestations may be because some endocrine glands express ACE2, such as thyroid and pancreas, or may be due to the hyperimmune feature of the cytokine storm. Adrenal insufficiency may occur as secondary adrenal insufficiency in COVID-19 patients as a result of pituitary hypofunction. Primary adrenal insufficiency is reported as a result of a thrombotic cause and it is a sign of worsening in ARDS. The unexplained body aches in COVID-19 patients may result from a defect in the hypothalamus-pituitary-adrenal axis, which leads to defective production of ACTH, causing secondary adrenal insufficiency (131-137) (129-135). Refer to Table 9.

\subsubsection{Discussion Point}

The endocrine manifestations of COVID-19 may occur as late manifestations. It has been reported in hospitalized patients. In addition, it may occur as an initial manifestation, such as 
TABLE 9 | Endocrine manifestation of COVID 19.

\begin{tabular}{|c|c|c|c|c|}
\hline Manifestations & Reference & Sample size & $\begin{array}{l}\text { Affected } \\
\text { patients }\end{array}$ & Incidence \\
\hline Ketosis & $\begin{array}{l}\mathrm{Li} \text {, Juyi et al. "COVID-19 infection may cause ketosis } \\
\text { and ketoacidosis." Diabetes, obesity \& metabolism vol. } \\
22,10 \text { (2020): 1935-1941. doi: } 10.1111 / \text { dom.14057 }\end{array}$ & 658 & $\begin{array}{l}42 \text { [no obvious } \\
\text { fever or } \\
\text { diarrhoea] }\end{array}$ & About $6.4 \%$ \\
\hline DKA & $\begin{array}{l}\mathrm{Li} \text {, Juyi et al. "COVID-19 infection may cause ketosis } \\
\text { and ketoacidosis." Diabetes, obesity \& metabolism vol. } \\
22,10 \text { (2020): 1935-1941. doi: } 10.1111 / \text { dom.14057 }\end{array}$ & $\begin{array}{l}658 \text { all the } \\
\text { patients }\end{array}$ & $\begin{array}{l}3 \text { patients had } \\
\text { DKA } \\
42 \text { had ketosis }\end{array}$ & $\begin{array}{l}0.455 \% \text { From total patient } \\
6.4 \% \text { out of } 658 \text { patients had } \\
\text { ketosis at admission time, they } \\
\text { have no obvious fever or } \\
\text { diarrhoea }\end{array}$ \\
\hline
\end{tabular}

Gentile, Sandro et al. "COVID-19, ketoacidosis and new-onset diabetes: Are there possible cause and effect relationships among them?." Diabetes, obesity \& metabolism vol. 22,12 (2020): 2507-2508. doi: $10.1111 /$ dom. 14170

New onset of hyperglycaemia

\section{Ghosh, Amerta, and Anoop Misra. "Marked} hyperglycemia and ketosis in a non-obese patient with new onset diabetes and very mild COVID-19 symptoms: A case report." Diabetes \& metabolic syndrome vol. 15,1 (2021): 213-214. doi: 10.1016/j.dsx.2020.12.036

Bode, Bruce et al. "Glycemic Characteristics and Clinical Outcomes of COVID-19 Patients Hospitalized in the United States." Journal of diabetes science and technology vol. 14,4 (2020): 813-821. doi: $10.1177 / 1932296820924469$

Abnormal thyroid
function
function

\section{defect in} hypothalamus pituitary axis

Chen, Min et al. "Thyroid Function Analysis in $\mathbf{5 0}$ Patients with COVID-19: A Retrospective Study." Thyroid : official journal of the American Thyroid Association, 10.1089/thy.2020.0363. 10 Jul. 2020, doi: 10.1089/thy.2020.0363

Adrenal insufficiency Almeida, Madson Q, and Berenice B Mendonca. "Adrenal Insufficiency and Glucocorticoid Use During the COVID-19 Pandemic." Clinics (Sao Paulo, Brazil) vol. 75 e2022. 12 Jun.

2020, doi: 10.6061/clinics/2020/e2022

Heidarpour, M., Vakhshoori, M., Abbasi, S. et al. Adrenal insufficiency in coronavirus disease 2019: a case report. J Med Case Reports 14, 134 (2020). https://doi. org/10.1186/s13256-020-02461-2

Hashim M, Athar S, Gaba WHNew onset adrenal insufficiency in a patient with COVID-19BMJ Case Reports CP 2021;14:e237690.

Alzahrani, Ali S et al. "The Impact of COVID-19 Viral Infection on the Hypothalamic-Pituitary-Adrenal Axis." Endocrine practice : official journal of the American College of Endocrinology and the American Association of Clinical Endocrinologists vol. 27,2 (2021): 83-89. doi: 10.1016/j.eprac.2020.10.014
Review diarrhoea
I Agree with this case result, Seen frequently in my practice in Field hospital FHOIA, HMC, Qatar

$1122 \quad 257 \quad$ About $22.9 \%$ of total patient

$30 \quad 64 \%$

review

case report

28

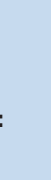

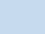

8

\section{0}

ACTH Le
10 in [7]
patients

Level $<20$ in

[17] patients

Level $<30$ in

[23] patients

Cortisol level

Level $<100$ in

[8] patients

Level $<200$ in

[14] patients

Level $<300$ in

[18] patients

Pancreatic injury

Bansal, Priya et al. "Pancreatic Injury in COVID-19

Patients." The Journal of the Association of Physicians

of India vol. 68,12 (2020): 58-60.

42

14 patients had

increase in

amylase level

29
7 patient had increase in lipase level
$25 \%$

$60.7 \%$

$82.1 \%$

$28.6 \%$

$50 \%$

$64.3 \%$

$33 \%$

$24.1 \%$ 
TABLE 10 | The defect in testosterone in COVID 19.

\begin{tabular}{|c|c|c|c|c|}
\hline The Defect & Reference & $\begin{array}{l}\text { The sample } \\
\text { size }\end{array}$ & $\begin{array}{l}\text { The affected } \\
\text { patients }\end{array}$ & Incidence \\
\hline \multirow{4}{*}{$\begin{array}{l}\text { Decrease Testosterone }[T] \text { level } \\
\text { Increase luteinizing hormone LH } \\
\text { T: LH may decrease in COVID } 19 \text { patient }\end{array}$} & $\begin{array}{l}\text { Okçelik, Sezgin. "COVID-19 pneumonia causes } \\
\text { lower testosterone levels." Andrologia, e13909. } \\
19 \text { Nov. } 2020 \text {, doi: } 10.1111 / \text { and.13909 }\end{array}$ & 24 & $\begin{array}{l}9 \text { patients have } \\
\text { low testosterone }\end{array}$ & $37.5 \%$ \\
\hline & & & $\begin{array}{l}7 \text { patients have } \\
\text { high LH }\end{array}$ & About $29 \%$ \\
\hline & $\begin{array}{l}\text { Wang, Zhengpin, and Xiaojiang Xu. } \\
\text { "scRNA-seq Profiling of Human Testes Reveals } \\
\text { the Presence of the ACE2 Receptor, A Target } \\
\text { for SARS-CoV-2 Infection in Spermatogonia, } \\
\text { Leydig and Sertoli Cells." Cells vol. } 9,4920.9 \\
\text { Apr. } 2020 \text {, doi: } 10.3390 / \text { cells } 9040920\end{array}$ & 16,632 cells & $\begin{array}{l}\text { ACE2 expression } \\
\text { finding in } \\
\text { testicular cells } \\
\text { with variations }\end{array}$ & $\begin{array}{l}\text { ACE2 represented as : } \\
1.4 \% \text { in spermatogonia } \\
4.25 \% \text { in Leydig and } \\
\text { Sertoli cells }\end{array}$ \\
\hline & $\begin{array}{l}\text { Yang, Ming et al. "Pathological Findings in the } \\
\text { Testes of COVID-19 Patients: Clinical } \\
\text { Implications." European urology focus vol. } 6,5 \\
\text { (2020): } 1124-1129 . \\
\text { doi: } 10.1016 / \text { j.euf.2020.05.009 }\end{array}$ & 12 & 11 & $\begin{array}{l}\text { About } 91 \% \text { have } \\
\text { testicular injury }\end{array}$ \\
\hline
\end{tabular}

DKA in COVID-19 patients with diabetic mellitus. COVID19 is one of the causes of ketosis and DKA in diabetes patients. ACE2 expression is found in many endocrine glands such as the thalamus, thyroid, pituitary, and pancreas, which explain the effect of COVID-19 on the endocrine system. The cytokine storm leads to multiorgan failure and plays a role in endocrine dysfunction. Blood tests for endocrine function may require monitoring of endocrine function in hospitalized COVID-19 patients.

\subsection{Testosterone Level (Male Reproductive System)}

Some studies have reported that testosterone (T) levels decreased in COVID-19 patients, while the luteinizing hormone (LH) levels increased. Therefore, the T: LH ratio may decrease in COVID19 patients (136). The authors mention the testes as one of the ACE2 receptor sites in the body; however, one study reported that no RNA of SARS-CoV-2 was found in testicular tissue biopsy of COVID-19 patients, but the decrease in the T level suggests Leydig cell damage in the testes $(137,138)$. However, one study suggested that high levels of cytokines in COVID-19 patients may lead to defects in the function of testes and spermatogonia (139). Refer to Table 10.

\subsubsection{Discussion Point}

Testosterone decline may be a complication of COVID-19. ACE2 expression is found in testicular tissue and may be affected by SARS-CoV-2. Cytokine storm has an effect on testicular function. Testosterone level follow-up is required for hospitalized male COVID-19 patients.

\subsection{Pregnancy}

ACE expression is found in the placenta and umbilical cord (140). Studies showed that neonates were infected with SARS-CoV2. There is no confirmed information about the time of viral infection from the mother to the fetus, whether it occurs in the first, second, or third trimester (141). Disturbance in maternalplacental blood flow was reported in pregnant patients with
COVID-19, and placental hypoxia was reported with systemic hypoxia as a result of COVID-19 in pregnant women $(142,143)$. Placental hypoxia and disturbance in placental blood flow may lead to a decrease in fetal growth, preterm birth, maternal death, and spontaneous abortion (144). Refer to Table 11.

\subsubsection{Discussion Points}

COVID-19 has an effect on pregnancy patients in the form of vertical transmission of the disease from the mother to the fetus through the umbilical cord. The effect of COVID-19 in pregnancy depended on the following factors: (1) direct effect of SARS-CoV-2 on ACE2 receptors on the umbilical cord and placenta, (2) effect of hypoxia on COVID-19 pneumonia, and (3) cytokine storm. Pregnant COVID-19 patients need observation and follow-up about fetal growth, placental blood flow, and maternal blood oxygen levels.

\subsection{Coagulopathy Manifestations}

Angiotensin-converting enzyme-2 has receptors on endothelial cells, indicating that SARS-CoV-2 has a direct effect on endothelial integrity that can induce VTE disease, which can cause deep vein thrombosis (DVT) and pulmonary embolism (PE) (145). The studies showed DVT and PE in hospitalized COVID-19 patients, especially in old and ICU patients (146). The D-dimer level increases in COVID-19 patients (147). Disseminated intermittent coagulopathy (DIC) is reported in many cases of hospitalized COVID-19 patients (148). Platelets could be decreased in COVID-19 (149). One study suggested that ACE2 receptors in platelets indicate the direct effect of SARS$\mathrm{CoV}-2$ on platelets, leading to platelet hyperactivity and increased thrombus formation (150). Refer to Table 12.

\subsubsection{Discussion Points}

Coagulopathy in COVID-19 leads to thromboembolic manifestations such as DVT, PE, and brain stroke. The endothelial cells has ACE2 receptors that may affected by SARS-COV2. So the blood vessels may lose their integrity, which leads to platelet aggregation and thrombus formation. DIC is a complication of COVID-19. The coagulopathy manifestations of 


$\begin{array}{lll}\text { COVID } 19 \text { effect in pregnancy } & \text { References } & \text { Sample size Affected } \\ \text { patients }\end{array}$

Mahyuddin, Aniza P et al. "Mechanisms and evidence of vertical transmission of infections in pregnancy including SARS-CoV-2s." Prenatal diagnosis vol. 40,13 (2020): 1655-1670. doi: 10.1002/pd.5765

Shanes, Elisheva D et al. "Placental Pathology in COVID-19." American journal of clinical pathology vol. 154,1 (2020): 23-32. doi: 10.1093/ajcp/aqaa089

Vertical infection

Disturbance in maternal placenta blood flow

Placental hypoxia

decrease in foetal growth, preterm birth, maternal death and

spontaneous abortion
Wenling, Yao et al. "Pregnancy and COVID-19: management and challenges." Revista do Instituto de Medicina Tropical de Sao Paulo vol. 62 (2020): e62. doi: 10.1590/s1678-9946202062062

Sheth, Sudip et al. "Outcomes in COVID-19 Positive Review

Neonates and Possibility of Viral Vertical

Transmission: A Narrative Review." American journal of perinatology vol. 37,12 (2020): 1208-1216. doi: 10.1055/s-0040-1714719

Chi J, Gong W, Gao Q. Clinical characteristics and outcomes of pregnant women with COVID-19 and the risk of vertical transmission: a systematic review. Arch Gynecol Obstet. 2020 Dec 1:1-9. doi: 10.1007/s00404-020-05889-5 Epub ahead of print. PMID: 33258995; PMCID: PMC7706177.
40 case series

\begin{tabular}{|c|c|c|}
\hline 15 & $\begin{array}{l}12 \text { cases had } \\
\text { maternal } \\
\text { vascular } \\
\text { mal-perfusion }\end{array}$ & $12 / 15$ \\
\hline \multicolumn{3}{|l|}{ Review } \\
\hline \multicolumn{3}{|l|}{ Review } \\
\hline $\begin{array}{l}\text { Systematic } \\
\text { review }\end{array}$ & 230 & $\begin{array}{l}34.62 \% \text { had obstetrics } \\
\text { complications }\end{array}$ \\
\hline
\end{tabular}

maternal

vascular

mal-perfusion

$34.62 \%$ had obstetrics $\begin{array}{lll}\text { Systematic } & 230 & 34.62 \% \text { had } \\ \text { review } & & \text { complications }\end{array}$ patients 
TABLE 12 | Coagulopathy manifestation of COVID 19

\section{Coagulopathy manifestations}

References

Sample size

Affected

patients

Effect on endothelial integrity that can induced venous thrombo embolic disease VTE as DVT and PE

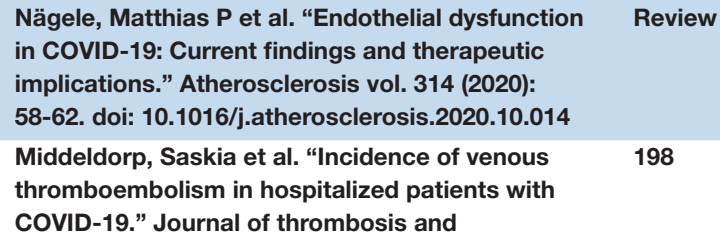

Incidence

$\begin{array}{lll}\text { DVT in } 26 & 13 \%\end{array}$

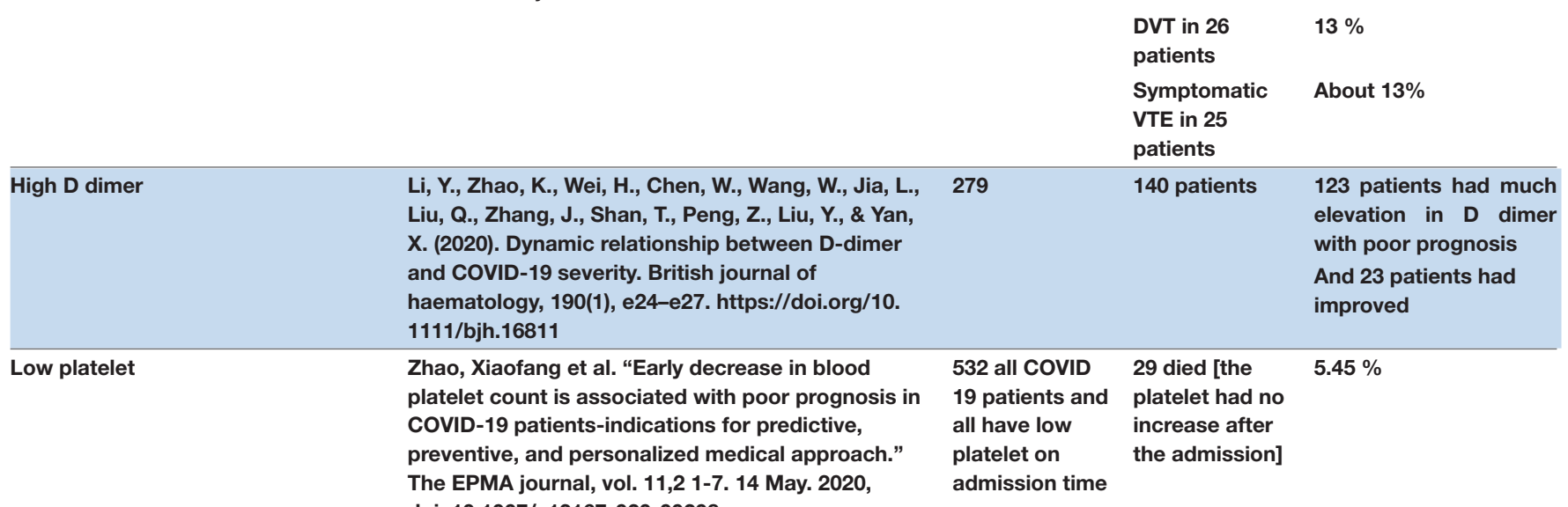

DIC doi: 10.1007/s13167-020-00208-z

Seitz, Rainer, and Wolfgang Schramm. "DIC in Letter to editor

COVID-19: Implications for prognosis and

treatment?." Journal of thrombosis and

haemostasis : JTH vol. 18,7 (2020): 1798-1799.

doi: $10.1111 /$ jth.14878

laboratory results occur as late manifestations or complications in moderate-severe cases of COVID-19.

\subsection{Musculoskeletal Manifestations}

Generalized bone ache and muscle pain were reported in COVID-19 patients (156). Rhabdomyolysis was reported in a COVID-19 patient with high CK and AKI (157). There are two mechanisms for muscle and bone aches in COVID-19 (161). The first is the direct effect of SARS-CoV-2 on the ACE 2 receptors in the muscle and cortex of the bone (158). The second mechanism is the inflammatory reaction of cytokine storm (164 and 161). Autoimmune myositis was reported in a COVID-19 patient (159). Generalized myopathy with muscle loss and weakness was reported in COVID-19 patients (110). Refer to Table 13.

\subsubsection{Discussion Point}

Coronavirus disease-140 presented with severe musculoskeletal pain in some people. The musculoskeletal manifestations may present as primary or initial symptoms or may present as late manifestations or complications such as myositis or myopathy. Rhabdomyolysis was reported in a COVID-19 patient that led to AKI.

\subsection{Initial Manifestations (Symptoms) of COVID-19}

The COVID-19 cases were divided into asymptomatic, mild, moderate, severe, and critical cases, according to the degree of infection and severity of the symptoms. Refer to Figures 1, 2.

The initial manifestations of COVID-19 vary. In the mild cases, the common symptoms were fever, cough, fatigue, musculoskeletal pain, headache, vomiting, loose motion, sore throat, cough, palpation, epigastric pain, and abdominal pain. COVID-19 coughs were reported to be an almost dry cough or sputum cough. In severe cases, the initial manifestations may be considered as high-risk symptoms such as respiratory failure, shock, respiratory distress, arrhythmia, AKI, severe bacterial infection may be secondary infection, sepsis, septic shock, and GIT bleeding. Peripheral neuropathy was reported as a primary manifestation of myopathy. A patient with a moderate case may present with shortness of breath (SOB) and bilateral pneumonia (160).

Usually, mild symptoms of COVID-19 are present in healthy young patients without any comorbidities. Severe symptoms may be present in patients with comorbidities or old age. Most at-risk patients who are exposed to COVID-19 may be old, pregnant, diabetic, and hypertensive, and have hepatic failure or 


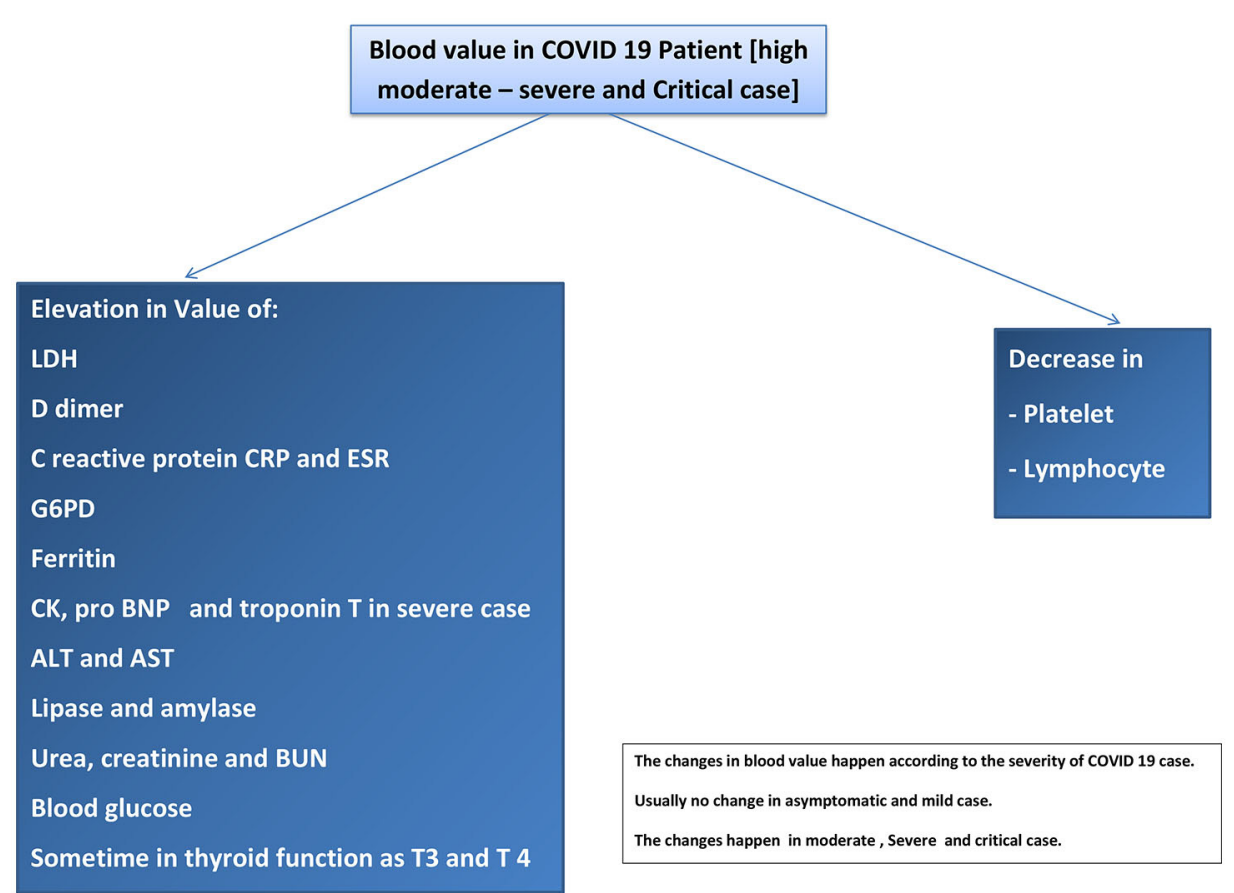

FIGURE 4 | Blood values in COVID-19 patients (high severe and critical cases).

TABLE 13 | Musculoskeletal manifestations of COVID 19. Journal of bone and joint surgery. American volume vol. 102,14 (2020): 1197-1204. doi: 10.2106/JBJS.20.00847

CDC. Symptoms of Coronavirus. CDC. Available at https://www.cdc.gov/ coronavirus/2019-ncov/symptoms-testing/symptoms.html. May 13, 2020; Accessed: June 26, 2020.

Rhabdomyolysis and increase in CK level Paliwal, V. K., Garg, R. K., Gupta, A., \& Tejan, N. (2020). Neuromuscular presentations in patients with COVID-19. Neurological sciences : official journal of the Italian Neurological Society and of the Italian Society of Clinical Neurophysiology, 41(11), 3039-3056. https://doi.org/10.1007/s10072-020-04708-8

Myositis

Beydon, Maxime et al. "Myositis as a manifestation of SARS-CoV-2." Annals of the rheumatic diseases, annrheumdis-2020-217573. 23 Apr. 2020, doi: 10.1136/annrheumdis-2020-217573

Myopathy

related conditions, ischaemic heart disease, and chronic kidney disease (160).

Mild symptoms with extra pulmonary manifestations need health care providers with good clinical sense to diagnose COVID-19 $(160,161)$.

Some COVID-19 patients may be asymptomatic and may continue to be asymptomatic until cure. Some of them present with severe symptoms. Some of the authors have used the term "pre-symptomatic phase" for some patients who were first asymptomatic but then presented with symptoms of COVID19. For example, many patients presented to the emergency department with an SOB, with low oxygen saturation, and with no history of cough or respiratory symptoms before and after the chest X-ray showed bilateral pulmonary infiltration in COVID-19 pneumonia. The incubation period for SARS-CoV2 is 14 days, as suggested in some studies, and some studies report 11.5 days; we refer to the period before the onset of symptoms as the asymptomatic phase or the pre-symptomatic phase $(161,162)$.

The critical case of COVID-19 presented with ARDS or multiple organ failure. Some of the critical cases started as mild symptoms then worsened, and some of them were asymptomatic 
and experienced ARDS or multiple organ failure as sudden attacks $(160,162)$.

One of the controversies is COVID-19 reinfection. Some studies have reported immunity toward COVID-19 after infection recovery. Some of the patients had no immunoglobulin IgM or IgG after recovery from infection, which may support the theory of reinfection of COVID-19. However, no case reported ARDS as a result of reinfection of COVID-19. Viral RNA may continue after the symptoms resolve during the recovery, but this does not mean that the patient still has a viral infection (161-163). Refer to Table 14.

\subsection{COVID-19 Manifestations and Diagnosis}

The COVID-19 manifestation can help diagnose COVID-19 patients by Suspicion. For example, the Infectious Disease Society of America recommends some symptoms for COVID-19 tests such as critical ill patient, unexplained pneumonia or respiratory failure, fever, lower respiratory tract symptoms, contact with a positive case of COVID-19 within 14 days, recent travel during 14 days, immunosuppressed patient with a respiratory infection or recent admission to the hospital, and health care worker with fever or respiratory tract infection. However, there are other symptoms of COVID-19 such as headache, loose motion and loss of smell, recent insomnia, palpitation, abdominal pain, epigastric pain, recent arrhythmia, recent brain injury (stroke or hemorrhage) in any age group, signs of recent peripheral neuropathy, and AKI, in addition, the unexplained acute liver or pancreatic injury, recent thyroid function, disturbance, recent abortion, preterm delivery, or sudden fetal death in pregnant woman. We have to consider a new onset of hypertension, especially in young patients, without a family history and newonset diabetes mellitus as probably symptoms of COVID19 infection. The principle is when the physician suspects COVID19 manifestations as either pulmonary or extrapulmonary, COVID-19, the investigations are required to rule out COVID-19 infection. May be in the future the COVID-19 PCR or COVID19 rapid antigen test will be routine investigations in some communities to rule out COVID-19 in unexplained symptoms or disease $(31,164)$.

Coronavirus disease investigations may involve laboratory or radiological investigations. Laboratory investigations include diagnostic studies such as the detection of SARS-CoV-2 RNA, antigen, or antibodies. Other laboratory tests may include leukopenia, leucocytosis, lymphopenia, increased LDH levels, high ferritin levels, unexplained ketosis, and high D-dimer levels (31).

The CT scan is a diagnostic tool for COVID-19, which reveals a bilateral ground-glass appearance that discovers silent pneumonia or the cause of silent hypoxia in many patients with COVID-19. The common feature of COVID-19 on a CT scan is the bilateral ground appearance; however, COVID19 features may appear on CT as follows: bilateral peripheral patches, bilateral reticular opacity, bilateral congestion or vascular thickness, unfrequented pleural effusion (reported), and lymphadenopathy. However, the American College of Radiology recommends avoiding the use of $\mathrm{CT}$ as a screening tool to diagnose COVID 19, which should be used only for hospitalized patients. Other studies have reported the effectiveness of CT scans in diagnosing asymptomatic COVID-19 patients (165, 166).

An X-ray can be used to diagnose COVID-19 patients, as the $\mathrm{X}$-ray findings in COVID-19 pneumonia are bilateral infiltration, patches, or glass-ground appearance (167).

\subsection{Radiological Manifestations of COVID-19}

We can explain the appearance of COVID-19 pneumonia in CT scans, such as multiple patches in the early phase, multiple ground-glass appearance in the moderate-to-severe case, and massive pulmonary consolidation in the severe case. As for X-ray findings, ground-glass appearance is the most common feature, followed by bilateral infiltration and multiple consolidations. Pleural effusion is infrequent, but has been reported $(167,168)$. Refer to Table 15.

\subsection{COVID-19 Manifestations in the Pediatric Patients}

The most common symptoms of COVID-19 in children are fever, cough, SOB, loose motion, abdominal pain, muscle ache, nasal flu, vomiting, nasal congestion, skin rash, conjunctivitis, sore throat, and loss of sense of taste and smell. X-ray radiography showed bilateral ground-glass appearance, bilateral patches, and consolidation (169-172). Refer to Table 16.

\subsection{Role of Genes in COVID-19 Manifestations}

Some authors believe in the role of the genes in determining the COVID-19 manifestations and the severity of the manifestations. The principle is that the ACE2 expression gene G8790A (rs2285666) has multiple polymorphisms (173). This means that it has different genotypes, such as A/A genotype, G/G genotype, and $\mathrm{C} / \mathrm{T}$ genotype (174). The authors believe that the gene has different genotypes according to ethnicity. Different genotypes mean different RNA sequences and may differ in the susceptibility to SARS-CoV-2, differ in manifestations, and severity of the manifestations (175). Some Italian authors believe that the ACE2 genotype $\mathrm{C} / \mathrm{T}$ is the most common in Italian people and is more susceptible to SARS-COV-2 than other genotypes in other ethnicities worldwide. The different susceptibility to SARS-CoV-2 means that some ethnicities are more affected by SARS-CoV-2 than others. Higher susceptibility means more severity and more critical manifestations, while low susceptibility means less severity with mild manifestations. Some researchers believe that some genotypes may confer resistance to SARS-CoV-2, which may explain asymptomatic patients (176).

On other hand, Some of the studies report that people with blood group A may have more susceptibility to COVID-19 in the severe form and manifestations, and those with blood group $\mathrm{O}$ may have low susceptibility and more resistance to COVID-19 $(177,178)$. 
TABLE 14 | COVID 19 manifestations in paediatric.

Fever, cough, shortness in breath, loose motion, abdominal pain, muscle ache, nasal flue, vomiting, nasal congestion, skin Rash, conjunctivitis, sore throat and loss of sense of taste and smell
CDC COVID-19 Response Team. Coronavirus disease 2019 in children United States, February 12-April 2, 2020. MMWR Morb Mortal Wkly Rep. 2020 Apr 10. 69 (14):422-6. [Medline].

Lu X, Zhang L, Du H, et al. SARS-CoV-2 infection in children. N Engl J Med. 2020 Apr 23. 382 (17):1663-65.

Castagnoli R, Votto M, Licari A, et al. Severe acute respiratory syndrome coronavirus 2 (SARS-CoV-2) infection in children and adolescents: a systematic review. JAMA Pediatr. 2020 Apr 22.

Foust AM, Phillips GS, Chu WC, et al. International expert consensus statement on chest imaging in pediatric COVID-19 patient management: imaging findings, imaging study reporting and imaging study recommendations. Radiology: Cardiothoracic Imaging. 2020 Apr 23. 2

TABLE 15 | Radiological manifestations for pulmonary COVID 19.

\section{The Radiological Manifestation}

The $X$ ray feature :

the ground glass appearance is commonest, bilateral infiltration, multiple consolidations and Pleural effusion is infrequent but reported

CT Feature :

multiple patches in early phase, multiple ground glass appearance in moderate - sever case and massive pulmonary consolidation in the sever case

\section{The References}

- ACR. ACR Recommendations for the use of Chest Radiography and Computed Tomography (CT) for Suspected COVID-19 Infection. American College of Radiology. Available at https://www.acr.org/Advocacy-and-Economics/ACRPosition-Statements/Recommendations-for-Chest-Radiography-and-CT-forSuspected-COVID19-Infection. March 22, 2020; Accessed: April 2, 2020.

Wang Y, Liu Y, Liu L, Wang X, Luo N, Ling L. Clinical outcome of 55 asymptomatic cases at the time of hospital admission infected with SARS-Coronavirus-2 in Shenzhen, China. J Infect Dis. 2020 Mar 17.

Bogoch, I. I., Watts, A., Thomas-Bachli, A., Huber, C., Kraemer, M., \& Khan, K. (2020). Pneumonia of unknown aetiology in Wuhan, China: potential for international spread via commercial air travel. Journal of travel medicine, 27(2), taaa008. https://doi.org/10.1093/jtm/taaa008

Li M, Lei P, Zeng B, Li Z, Yu P, Fan B, et al. Coronavirus Disease (COVID-19): Spectrum of CT Findings and Temporal Progression of the Disease. Acad Radiol. 2020 Mar 20.

TABLE 16 | The initial manifestations [symptoms] of COVID 19.

$\begin{array}{ll}\text { The Manifestations } & \text { References }\end{array}$

Mild symptoms :

Fever, cough, Fatigue, musculoskeletal pain, Headache, vomiting, loose motion, sore throat, cough, palpation, epigastric pain and abdominal pain

The moderate case may present as SOB and bilateral pneumonia.

\section{Sever symptoms :}

respiratory failure, shock, respiratory distress, arrhythmia, Acute kidney injury AKI, sever bacterial infection may as secondary infection, sepsis, septic shock, GIT bleeding

Critical case :

as acute respiratory distress syndrome or multiple organs failure
- CDC. Symptoms of Coronavirus. CDC. Available at https://www.cdc.gov/ coronavirus/2019-ncov/symptoms-testing/symptoms.html. May 13, 2020; Accessed: June 26, 2020.

CDC. Coronavirus Disease 2019 (COVID-19): Evaluating and Testing PUI. Centers for Disease Control and Prevention. Available at https://www.cdc.gov/ coronavirus/2019-ncov/hcp/clinical-criteria.html. May 3, 2020; Accessed: June 9, 2020.

CDC. Interim Clinical Guidance for Management of Patients with Confirmed Coronavirus Disease (COVID-19). CDC. Available at https://www.cdc.gov/ coronavirus/2019-ncov/hcp/clinical-guidance-management-patients.html. June 2, 2020; Accessed: June 9, 2020

Gousseff, Marie et al. "Clinical recurrences of COVID-19 symptoms after recovery: Viral relapse, reinfection or inflammatory rebound?." The Journal of infection vol. 81,5 (2020): 816-846. doi: 10.1016/j.jinf.2020.06.073

\subsection{COVID-19 Manifestation and Management}

COVID-19 patients were managed according to severity, the intensity of the manifestations, and type of manifestation, i.e., pulmonary and extrapulmonary. The asymptomatic case can be managed by isolation and quarantine, with a full observation of any symptoms that may be discovered by the patient. The mild case of COVID-19 may require quarantine with symptomatic treatment and close observation (179). The severe and moderate cases may require hospitalization, images (chest X-ray, CT scan according to the patient status), blood investigations, symptomatic treatment, and other types of management, specific 
to COVID-19, such as remdesvir, bamlanivimab, convalescent plasma, and baricitinib in children (2 years and above). For pulmonary manifestations, oxygen supplementation and mechanical ventilation are required according to the severity of the case. Some research and studies support the use of dexamethasone as a treatment in COVID-19 lower respiratory cases (180-182).

Remdesivir has received emergency use approval (EUA) by the Food and Drug Administration (FDA) on October 20, 2020. It is an antiviral treatment for adult patients and children from 12 years and above. Convalescent plasma was also approved as EUA by the FDA in August 2020. Bamlanivimab was approved for EUA by the FDA on November 9, 2020, and baricitinib was approved by the FDA as EUA on November 19, 2020 (183-185). Some researchers have suggested the use of reninangiotensin system blockers in COVID-19 management. One hypothesis indicated that ACE2 receptor expression may increase with the use of ACE blockers, which may increase the severity of infections and manifestations. However, another study showed no difference in the outcome between the two groups of COVID19 patients, wherein one group used an ACE blocker whereas the other one did not use an ACE blocker. The American Heart Association does not advise the initiation of ACE blockers and that its use should be stopped in COVID-19 patients $(186,187)$.

Chloroquine and hydroxychloroquine are no longer recommended in the management of COVID-19; the FDA revoked the EUA on June 15, 2020. Studies showed no significant effect between the two groups: one used chloroquine, while the other did not. Choloroquine is an antimalarial drug that can be used to control the inflammatory response in the body as SLE and rheumatoid arthritis; however, its use may induce a dangerous cardiac side effect $(179,188,189)$.

Coronavirus disease-2019 patients may have coagulopathy that leads to microangiopathy, DVT, and PE. Antithrombotic therapy may be required in critically ill patients who are on mechanical ventilator support or they may require ICU admission to decrease mortality. Low-dose anticoagulants may prevent the deterioration of severe symptoms in hospitalized patients $(190,191)$.

Many COVID-19 patients developed new-onset diabetes mellitus as a result of pancreatic defects from COVID-19. Insulin should be used to treat diabetes in patients with COVID-19. Hospitalization is required for obese and chronic diabetes patients with COVID-19. The hypoglycaemic agent thiazolidinedione upregulates ACE2 receptors $(33,192,193)$.

A British study showed a decrease in the mortality rate in patients who received low-dose dexamethasone $6 \mathrm{mg}$ per day in comparison with other usual treatment patients. Corticosteroids may be recommended as a treatment for ARDS and septic shock. It is not useful in cardiogenic shock. Hydrocortisone $50 \mathrm{mg}$ every $8 \mathrm{~h}$ per day can be useful in critically-ill COVID-19 patients (194196).

Arrhythmia and cardiac manifestations in COVID-19 should be managed according to the guidelines of the European Resuscitation Council (ERC) and the American Heart Association (AHA) (67).
Other medications such as immunomodulators, including interleukin inhibitors and interferons, statins, and nitric oxide are still under study. Some natural supplements, such as zinc and vitamin D, are recommended (197-200).

Phosphodiesterase inhibitors, such as ibudilast, may be used as a macrophage migration inhibitor to manage the cytokine storm. It has been approved for use in Japan and South Korea for the treatment of bronchial asthma since 1989. In the USA, ibudilast has been approved by the FDA after trials (201).

Azithromycin and hydroxychloroquine are no longer recommended for use in the management of COVID19. Studies showed no significant or clinical benefits in patients with hydroxychloroquine/azithromycin in comparison with other patients who did not use these drugs. Hydroxychloroquine/azithromycin may induce QT prolongation and cardiovascular mortality in COVID-19 patients $(202,203)$.

Empirical antibiotics are required for severe acute respiratory symptoms and septic symptoms (196).

\section{CONCLUSION}

COVID-19 is not only respiratory disease but also a multisystem disease, and respiratory symptoms may be present or absent in COVID-19 patients according to multiple factors such as viral overloading, genetic factors, immune reactions, cytokine storm, and comorbidities. The other frequent symptoms are gastrointestinal symptoms and fever. According to the severity of the case, the patient may also have renal, VTE, cardiac, or central nervous system manifestations. Skin and ocular manifestations have also been reported. In addition, peripheral neural disease was also reported in COVID-19 patients. The pathophysiology depends on ACE2 expression, cytokine storms, and side effects of the drugs used. The extra pulmonary manifestations of COVID19 should not be neglected and should be fully considered for the early diagnosis and prevention of the spread of COVID-19.

\section{RECOMMENDATIONS}

We suggest changing the COVID-19 virus name from severe acute respiratory syndrome-Corona Virus two (SARS-CoV2) to severe respiratory and multisystem syndrome-Corona Virus Two (SRMS-CoV-2) or (SRAMS-CoV-2) because COVID-19 is not only respiratory disease but also a multisystem disease. We suggest that, in addition to the name change, extra pulmonary manifestations should not be ignored by healthcare providers and should be considered during the diagnosis and management of COVID 19.

\section{AUTHOR CONTRIBUTIONS}

This article was completed in partial requirement for the MSc in Acute Medicine from the University of South Wales, UK. IE was the student and data collector. $\mathrm{KN}$ was a supervisor and tutor. Both authors contributed to the article and approved the submitted version. 


\section{REFERENCES}

1. World Health Organization. Director-General's Remarks at the Media Briefing on 2019-nCoV on 11 February 2020 2020). Available online at: https://www.who.int/dg/speeches/detail/who-director-general-s-remarksat-the-media-briefing-on-2019-ncov-on-11-february-2020 (accessed February 12, 2020).

2. World Health Organization. Novel Coronavirus (2019-nCoV) Technical Guidance (2020). Available online at: https:/www.who.int/emergencies/ diseases/novel-coronavirus-2019/technical-guidance (accessed Feburary 14, 2020).

3. Bajema KL, Oster AM, McGovern OL, Stenger MR, Anderson TC, Cheryl Isenhour DVM, et al. Persons Evaluated for 2019 Novel Coronavirus - United States. MMWR. MMWMorbidity R and Mortality Weekly Report (2020).

4. Chan JF, Yuan S, Kok KH, To KK, Chu H, Yang J, et al. A familial cluster of pneumonia associated with the 2019 novel coronavirus indicating personto-person transmission: a study of a family cluster. Lancet. (2020) 395:514523. doi: 10.1016/S0140-6736(20)30154-9

5. Yang X, Yu Y, Xu J, Shu H, Xia J, Liu H, et al. Clinical course and outcomes of critically ill patients with SARS-CoV-2 pneumonia in Wuhan, China: a single-centered, retrospective, observational study. Lancet Respir Med. (2020) 8:475-81. doi: 10.1016/S2213-2600(20)30079-5

6. World Health Organization. WHO Director, 2019-. General's Remarks at the Media Briefing On. $n \mathrm{CoV}$ (2020). Available online at: https://www. who.int/dg/speeches/detail/who-director-general-s-remarks- at- the-mediabriefing-on-2019-ncov-on-11-february-2020 (accessed Feburary 11, 2020).

7. Wu Z, McGoogan JM. Characteristics of and important lessons from the coronavirus disease (2019) (COVID-19) outbreak in China: summary of a report of 72314 cases from the Chinese Center for Disease Control and Prevention, JAMA. (2020) 323:1239-42. doi: 10.1001/jama.2020.2648

8. Grasselli G, Pesenti A, Cecconi M. Critical care utilization for the COVID-19 outbreak in Lombardy, Italy: early experience and forecast during an emergency response. JAMA. (2020) 323:1545-6. doi: 10.1001/jama.2020.4031

9. Onder G, Rezza G, Brusaferro S. Case-fatality rate and characteristics of patients dying in relation to COVID-19 in Italy. JAMA. (2020) 323:17756. doi: $10.1001 /$ jama.2020.4683

10. Richardson S, Hirsch JS, Narasimhan M, Crawford JM, McGinn T, Davidson KW, et al. Presenting characteristics, comorbidities, and outcomes among 5700 patients hospitalized with COVID-19 in the New York City area. JAMA. (2020) 323:2052-9. doi: 10.1001/jama.2020.6775

11. Centers for Disease Control and Prevention. Symptoms of Coronavirus (2020). Available online at: https://www.cdc.gov/coronavirus/ 2019-ncov/symptoms-testing/symptoms.html (accessed February 22, 2021).

12. Khan S, Siddique R, Shereen MA, Ali A, Liu J, Bai Q, et al. Emergence of a novel coronavirus, severe acute respiratory syndrome coronavirus 2: biology and therapeutic options. J Clin Microbiol. (2020) 58:5. doi: 10.1128/JCM.00187-20

13. Chen Y, Guo Y, Pan Y, Zhao ZJ. Structure analysis of the receptor binding of 2019-nCoV. Biochem Biophys Res Commun. (2020) 525:13540. doi: 10.1016/j.bbrc.2020.02.071

14. Wrapp D, Wang N, Corbett KS, Goldsmith JA, Hsieh CL, Abiona O, et al. Cryo-EM structure of the 2019-nCoV spike in the prefusion conformation. Science. (2020) 367:1260-3. doi: 10.1126/science.abb2507

15. Goren A, McCoy J, Wambier CG, Vano-Galvan S, Shapiro J, Dhurat $\mathrm{R}$, et al. What does androgenetic alopecia have to do with COVID19, an insight into a potential new therapy. Dermatol Ther. (2020) 33:e13365. doi: 10.1111/dth.13365

16. Kabbani N, Olds JL. Does COVID19 infect the brain? If so, smokers might be at a higher risk. Mol Pharmacol. (2020) 97:351-3. doi: 10.1124/molpharm.120.000014

17. Zou X, Chen K, Zou J, Han P, Hao J, Han Z. Single-cell RNAseq data analysis on the receptor ACE2 expression reveals the potential risk of different human organs vulnerable to 2019-nCoV infection. Front Med. (2020) 14:185-92. doi: 10.1007/s11684-0200754-0

18. Fahmy DH, El-Amawy HS, El-Samongy MA, Fouda AA, Soliman SH, El-Kady A, et al. COVID-19 and dermatology: a comprehensive guide for dermatologists. J Eur Acad Dermatol Venereol. (2020) 34:1388-94. doi: 10.1111/jdv.16545

19. Puliatti S, Eissa A, Eissa R, Amato M, Mazzone E, Dell'Oglio P, et al. COVID19 and urology: a comprehensive review of the literature. BJU Int. (2020) 125:E7-14. doi: 10.1111/bju.15071

20. Skeegs LT, Kahn JE, Shumway NP. The preparation and function of the angiotensin-converting enzyme. J Exp Med. (1956) 103:2959. doi: $10.1084 /$ jem.103.3.295

21. Wang W, McKinnie SM, Farhan M, Paul M, McDonald T, McLean B, et al. Angiotensin-converting enzyme 2 metabolizes and partially inactivates pyr-apelin-13 and apelin-17: physiological effects in the cardiovascular system. Hypertension. (2016) 68:365-77. doi: 10.1161/HYPERTENSIONAHA.115.06892

22. Chamsi-Pasha MA, Shao Z, Tang WH. Angiotensin-converting enzyme 2 as a therapeutic target for heart failure. Curr Heart Fail Rep. (2014) 11:5863. doi: 10.1007/s11897-013-0178-0

23. Wang H, Yang P, Liu K, Guo F, Zhang Y, Zhang G, et al. SARS coronavirus entry into host cells through a novel clathrin- and caveolae-independent endocytic pathway. Cell Res. (2008) 18:290-301. doi: 10.1038/cr.2008.15

24. Chen IY, Moriyama M, Chang MF, Ichinohe T. Severe acute respiratory syndrome coronavirus viroporin 3a activates the NLRP3 inflammasome. Front Microbiol. (2019) 10:50. doi: 10.3389/fmicb.2019.00050

25. Zhou Y, Fu B, Zheng X, Wang D, Zhao C, Qi Y, et al. Pathogenic T-cells and inflammatory monocytes incite inflammatory storms in severe COVID-19 patients. Natl Sci Rev. (2020) 7:998-1002. doi: 10.1093/nsr/nwaa041

26. Chen L, Liu $M$, Zhang $Z$, Qiao $K$, Huang $T$, Chen $M$, et al. Ocular manifestations of a hospitalised patient with confirmed 2019 novel coronavirus disease. Br J Ophthalmol. (2020) 104:748-51. doi: 10.1136/bjophthalmol-2020-316304

27. Chen L, Deng C, Chen X, Zhang X, Chen B, Yu H, et al. Ocular manifestations and clinical characteristics of 535 cases of COVID-19 in Wuhan, China: a cross-sectional study. Acta Ophthalmol. (2020) 98:e9519. doi: $10.1111 /$ aos. 14472

28. Baig AM. Neurological manifestations in COVID-19 caused by SARS-CoV2. CNS Neurosci Ther. (2020) 26:499-501. doi: 10.1111/cns.13372

29. Grasselli G, Zangrillo A, Zanella A, Antonelli M, Cabrini L, Castelli A, et al. Baseline characteristics and outcomes of 1591 patients infected with SARS-CoV-2 admitted to ICUs of the Lombardy Region, Italy. JAMA. (2020) 323:1574-81. doi: 10.1001/jama.2020.5394

30. Guan WJ, Ni ZY, Hu Y, Liang WH, Ou CQ, He JX, et al. Clinical characteristics of coronavirus disease 2019 in China. N Engl J Med. (2020) 382:1708-20. doi: 10.1056/NEJMoa2002032

31. Huang C, Wang Y, Li X, Ren L, Zhao J, Hu Y, et al. Clinical features of patients infected with 2019 novel coronavirus in Wuhan, China. Lancet. (2020) 395:497-506. doi: 10.1016/S0140-6736(20)30183-5

32. South AM, Brady TM, Flynn JT. ACE2 (angiotensin-converting Enzyme 2), COVID-19, and ACE Inhibitor and Ang II (angiotensin II) receptor blocker use during the pandemic: the pediatric perspective. Hypertension. (2020) 76:16-22. doi: 10.1161/HYPERTENSIONAHA.120.15291

33. National Center for Biotechnology Information (NCBI). Gene: ACE2, Angiotensin I Converting Enzyme 2. US National Library of Medicine (2020). Available online at: https://www.ncbi.nlm.nih.gov/gene/59272 (accessed August 16, 2021).

34. Luo Y, Liu C, Guan T, Li Y, Lai Y, Li F, et al. Association of ACE2 genetic polymorphisms with hypertension-related target organ damages in south Xinjiang. Hypertens Res. (2019) 42:681-9. doi: 10.1038/s41440-018-0166-6

35. Cao Y, Li L, Feng Z, Wan S, Huang P, Sun X, et al. Comparative genetic analysis of the novel coronavirus (2019-nCoV/SARS-CoV2) receptor ACE2 in different populations. Cell Discov. (2020) 6:11. doi: 10.1038/s41421-020-0147-1

36. Yang J, Zheng Y, Gou X, Pu K, Chen Z, Guo Q, et al. Prevalence of comorbidities in the novel Wuhan coronavirus (COVID-19) infection: a systematic review and meta-analysis. Int J Infect Dis. (2020) 94:915. doi: 10.1016/j.ijid.2020.03.017

37. Jordan RE, Adab P, Cheng KK. Covid-19: risk factors for severe disease and death. BMJ. (2020) 368:m1198. doi: 10.1136/bmj.m1198

38. Chen Y, Li L. SARS-CoV-2: virus dynamics and host response. Lancet Infect Dis. (2020) 20:515-6. doi: 10.1016/S1473-3099(20)30235-8 
39. Zhou F, Yu T, Du R, Fan G, Liu Y, Liu Z, et al. Clinical course and risk factors for mortality of adult inpatients with COVID-19 in Wuhan, China: a retrospective cohort study. Lancet. (2020) 395:105462. doi: 10.1016/S0140-6736(20)30566-3

40. Verity R, Okell LC, Dorigatti I, Winskill P, Whittaker C, Imai N, et al. Estimates of the severity of coronavirus disease 2019: a model-based analysis. Lancet Infect Dis. (2020) 20:669-77. doi: 10.1016/S1473-3099(20)30243-7

41. Wei C, Liu Y, Liu Y, Zhang K, Su D, Zhong M, et al. Clinical characteristics and manifestations in older patients with COVID-19. BMC Geriatr. (2020) 20:395. doi: 10.1186/s12877-020-01811-5

42. Liu K, Chen Y, Lin R, Han K. Clinical features of COVID-19 in elderly patients: a comparison with young and middle-aged patients. J Infectol. (2020) 80:e14-8. doi: 10.1016/j.jinf.2020.03.005

43. Klein SL, Flanagan KL. Sex differences in immune responses. Nat Rev Immunol. (2016) 16:626-38. doi: 10.1038/nri.2016.90

44. Cai H. Sex difference and smoking predisposition in patients with COVID19. Lancet Respir. Med. (2020) 8:e20. doi: 10.1016/S2213-2600(20)30117-X

45. Ryan DH, Ravussin E, Heymsfield S. COVID 19 and the patient with obesity - the editors speak out. Obesity (Silver Spring). (2020) 28:847. doi: 10.1002/oby.22808

46. Peng YD, Meng K, Guan HQ, Leng L, Zhu RR, Wang BY, et al. [Clinical characteristics and outcomes of 112 cardiovascular disease patients infected by 2019-nCoV]. Zhonghua Xin Xue Guan Bing Za Zhi. (2020) 48:450-5. doi: 10.3760/cma.j.cn112148-20200220-00105

47. Wu J, Li W, Shi X, Chen Z, Jiang B, Liu J, et al. Early antiviral treatment contributes to alleviate the severity and improve the prognosis of patients with novel coronavirus disease (COVID-19). J Intern Med. (2020) 288:12838. doi: 10.1111/joim.13063

48. Cai Q, Chen F, Wang T, Luo F, Liu X, Wu Q, et al. Obesity and COVID-19 severity in a designated hospital in Shenzhen, China. Diabetes Care. (2020) 43:1392-8. doi: 10.2337/dc20-0576

49. Goyal P, Choi JJ, Pinheiro LC, Schenck EJ, Chen R, Jabri A, et al. Clinical characteristics of Covid-19 in New York City. N Engl J Med. (2020) 382:23724. doi: 10.1056/NEJMc2010419

50. Maier HE, Lopez R, Sanchez N, Ng S, Gresh L, Ojeda S, et al. Obesity increases the duration of influenza A virus shedding in adults. J Infect Dis. (2018) 218:1378-82. doi: 10.1093/infdis/jiy370

51. Tang Y, Liu J, Zhang D, Xu Z, Ji J, Wen C. Cytokine storm in COVID19: the current evidence and treatment strategies. Front Immunol. (2020) 11:1708. doi: 10.3389/fimmu.2020.01708

52. Mehta P, McAuley DF, Brown M, Sanchez E, Tattersall RS, Manson JJ, et al. COVID-19: consider cytokine storm syndromes and immunosuppression. Lancet. (2020) 395:1033-4. doi: 10.1016/S0140-6736(20)30 628-0

53. Schett G, Sticherling M, Neurath MF. COVID-19: risk for cytokine targeting in chronic inflammatory diseases? Nat Rev Immunol. (2020) 20:2712. doi: 10.1038/s41577-020-0312-7

54. Das S, Johnson DB. Immune-related adverse events and anti-tumor efficacy of immune checkpoint inhibitors. J Immunother Cancer. (2019) 7:306. doi: 10.1186/s40425-019-0805-8

55. Murthy H, Iqbal M, Chavez JC, Kharfan-Dabaja MA. Cytokine release syndrome: current perspectives. Immuno Targets Ther. (2019) 8:4352. doi: 10.2147/ITT.S202015

56. Anderson R, Rapoport BL. Immune dysregulation in cancer patients undergoing immune checkpoint inhibitor treatment and potential predictive strategies for future clinical practice. Front Oncol. (2018) 8:80. doi: 10.3389/fonc.2018.00080

57. Ge H, Wang X, Yuan X, Xiao G, Wang C, Deng T, et al. The epidemiology and clinical information about COVID-19. Eur J Clin Microbiol Infect Dis. (2020) 39:1011-9. doi: 10.1007/s10096-020-03874-Z

58. Zhou M, Zhang X, Qu J. Coronavirus disease 2019. (COVID-19): a clinical update. Front Med. (2020) 14:126-35. doi: 10.1007/s11684-020-0767-8

59. He F, Deng Y, Li W. Coronavirus disease 2019: what we know? J Med Virol. (2020) 92:719-25. doi: 10.1002/jmv.25766

60. Teo J. Early detection of silent hypoxia in Covid-19 pneumonia using smartphone pulse oximetry. J Med Syst. (2020) 44:134. doi: 10.1007/s10916-020-01587-6
61. Wu F, Zhao S, Yu B, Chen YM, Wang W, Song ZG, et al. A new coronavirus associated with human respiratory disease in China. Nature. (2020) 579:2659. doi: 10.1038/s41586-020-2008-3

62. Tian S, Hu W, Niu L, Liu H, Xu H, Xiao SY. Pulmonary pathology of early-phase 2019 novel coronavirus (COVID-19) pneumonia in two patients with lung cancer. J Thorac Oncol. (2020) 15:700-4. doi: 10.1016/j.jtho.202 0.02 .010

63. Tian S, Xiong Y, Liu H, Niu L, Guo J, Liao M, et al. Pathological study of the 2019 novel coronavirus disease (COVID-19) through postmortem core biopsies. Mod Pathol. (2020) 33:1007-14. doi: 10.1038/s41379-020-0 $536-x$

64. Zhang H, Zhou P, Wei Y, Yue H, Wang Y, Hu M, et al. Histopathologic changes and SARSCoV- 2 immunostaining in the lung of a patient eith COVID-19. Ann Intern Med. (2020) 172:629-32. doi: 10.7326/M20-0533

65. Ascierto PA, Fox BA, Urba WJ, Anderson AC, Atkins MB, Borden EC, et al. Insights from immuno-oncology: the Society for Immunotherapy of Cancer statement on access to IL-6-targeting therapies for COVID-19. J Immunother Cancer. (2020) 8:e000930. doi: 10.1136/jitc-2020-000878

66. Zheng YY, Ma YT, Zhang JY, Xie X. COVID-19 and the cardiovascular system. Nat Rev Cardiol. (2020) 17:259-60. doi: 10.1038/s41569-020-0360-5

67. Kang Y, Chen T, Mui D, Ferrari V, Jagasia D, Scherrer-Crosbie M, et al. Cardiovascular manifestations and treatment considerations in COVID-19. Heart. (2020) 106:1132-41. doi: 10.1136/heartjnl-2020-317056

68. Madjid M, Safavi-Naeini P, Solomon SD, Vardeny O. Potential effects of coronaviruses on the cardiovascular system: a review. JAMA Cardiol. (2020) 5:831-40. doi: 10.1001/jamacardio.2020.1286

69. Nishiga M, Wang DW, Han Y, Lewis DB, Wu JC. COVID-19 and cardiovascular disease: from basic mechanisms to clinical perspectives. Nat Rev Cardiol. (2020) 17:543-58. doi: 10.1038/s41569-020-0413-9

70. Lippi G, Lavie CJ, Sanchis-Gomar F. Cardiac troponin I in patients with coronavirus disease (2019). (COVID-19): evidence from a meta-analysis. Prog Cardiovasc Dis. (2020) 63:390-91. doi: 10.1016/j.pcad.2020.03.001

71. Lala A, Johnson KW, Januzzi JL, Russak AJ, Paranjpe I, Richter $\mathrm{F}$, et al. Prevalence and impact of myocardial injury in patients hospitalized with COVID-19 infection. J Am Coll Cardiol. (2020) 76:53346. doi: 10.1016/j.jacc.2020.06.007

72. Long B, Brady WJ, Koyfman A, Gottlieb M. Cardiovascular complications in COVID-19. Am J Emerg Med. (2020) 38:15047. doi: 10.1016/j.ajem.2020.04.048

73. Sattar Y, Ullah W, Rauf H, Virk HUH, Yadav S, Chowdhury M, et al. COVID-19 cardiovascular epidemiology, cellular pathogenesis, clinical manifestations and management. Int J Cardiol Heart Vasc. (2020) 29:100589. doi: 10.1016/j.ijcha.2020.100589

74. Bottiroli M, De Caria D, Belli O, Calini A, Andreoni P, Siragusa A, et al. Takotsubo syndrome as a complication in a critically ill COVID-19 patient. ESC Heart Fail. (2020) 7:4297-300. doi: 10.1002/ehf2.12912

75. Shi S, Qin M, Shen B, Cai Y, Liu T, Yang F, et al. Association of cardiac injury with mortality in hospitalized patients with COVID-19 in Wuhan, China. JAMA Cardiol. (2020) 5:802-10. doi: 10.1001/jamacardio.2020.0950

76. Lee IC, Huo TI, Huang YH. Gastrointestinal and liver manifestations in patients with COVID-19. J Chin Med Assoc. (2020) 83:5213. doi: 10.1097/JCMA.0000000000000319

77. Wong SH, Lui RN, Sung JJ. Covid-19 and the digestive system. J Gastroenterol Hepatol. (2020) 35:744-8. doi: 10.1111/jgh.15047

78. Su H, Yang M, Wan C, Yi LX, Tang F, Zhu HY, et al. Renal histopathological analysis of 26 postmortem findings of patients with COVID-19 in China. Kidney Int. (2020) 98:219-27. doi: 10.1016/j.kint.2020.04.003

79. Fang D, Jingdong MA, Guan J, Wang M, Song J, Tian D, et al. Manifestations of digestive system in hospitalized patients with novel coronavirus pneumonia in Wuhan, China: a single-center, descriptive study. Chin J Dig. (2020) 40:E005. Available online at: https://pesquisa.bvsalud.org/globalliterature-on-novel-coronavirus-2019-ncov/resource/en/covidwho-2296 (accessed August 17, 2021).

80. Shinu P, Morsy MA, Deb PK, Nair AB, Goyal M, Shah J, et al. SARS CoV-2 organotropism associated pathogenic relationship of gut-brain axis and illness. Front Mol Biosci. (2020) 7:606779. doi: 10.3389/fmolb.2020. 606779 
81. Wan Y, Li J, Shen L, Zou Y, Hou L, Zhu L, et al. Enteric involvement in hospitalised patients with COVID-19 outside Wuhan. Lancet Gastroenterol. Hepatol. (2020) 5:534-5. doi: 10.1016/S2468-1253(20)30118-7

82. Cardoso FS, Pereira R, Germano N. Liver injury in critically ill patients with COVID-19: a case series. Crit Care. (2020) 24:190. doi: 10.1186/s13054-020-02924-4

83. Liu F, Long X, Zhang B, Zhang W, Chen X, Zhang Z. ACE2 expression in pancreas may cause pancreatic damage after SARS-CoV-2 infection. Clin Gastroenterol Hepatol. (2020) 18:2128-30.e2. doi: 10.1016/j.cgh.2020. 04.040

84. Tao YY, Tang LV, Hu Y. Treatments in the COVID-19 pandemic: an update on clinical trials. Expert Opin Emerg Drugs. (2020) 25:818. doi: 10.1080/14728214.2020.1773431

85. Nobel YR, Phipps M, Zucker J, Lebwohl B, Wang TC, Sobieszczyk ME, et al. Gastrointestinal symptoms and COVID-19: casecontrol study from the United States. Gastroenterology. (2020) 59:373-5.87. doi: 10.1053/j.gastro.2020.04.017

86. Tian Y, Rong L, Nian W, He Y. Review article: gastrointestinal features in COVID-19 and the possibility of faecal transmission. Aliment Pharmacol Ther. (2020) 51:843-51. doi: 10.1111/apt.15731

87. Benites-Goñi H, Pascacio-Fiori M, Monge-Del Valle F, Plácido-Damián Z, Gonzales-Carazas E, Padilla-Espinoza M, et al. Impact of the COVID-19 pandemic in the time to endoscopy in patients with upper gastrointestinal bleedin. Rev Gastroenterol Peru. (2020) 40:219-23.

88. Chu KH, Tsang WK, Tang CS, Lam MF, Lai FM, To KF, et al. Acute renal impairment in coronavirus-associated severe acute respiratory syndrome. Kidney Int. (2005) 67:698-705. doi: 10.1111/j.1523-1755.2005.67130.x

89. Naicker S, Yang CW, Hwang SJ, Liu BC, Chen JH, Jha V. The novel coronavirus 2019 epidemic and kidneys. Kidney Int. (2020) 97:8248. doi: 10.1016/j.kint.2020.03.001

90. Pei, G.uangchang, Zhang Z, Peng J, Liu L, Zhang C, et al. Renal involvement and early prognosis in patients with COVID-19 pneumonia. J Am Soc Nephrol. (2020) 31:1157-65. doi: 10.1681/ASN.2020030276

91. Hamming I, Timens W, Bulthuis MLC, Lely AT, Navis G, van Goor. H. Tissue distribution of ACE2 protein, the functional receptor for SARS coronavirus. A first step in understanding SARS pathogenesis. J Pathol. (2004) 203:6317. doi: 10.1002 /path. 1570

92. Angel-Korman A, Brosh T, Glick K, Leiba A. COVID-19, the kidney and hypertension. Harefuah. (2020) 159:231-4.

93. Zheng S, Fan J, Yu F, Feng B, Lou B, Zou Q, et al. Viral load dynamics and disease severity in patients infected with SARS-CoV-2 in Zhejiang Province, China, January-March 2020: retrospective cohort study. BMJ (Clin. Res. Ed.). (2020) 369:m1443. doi: 10.1136/bmj.m1443

94. Nicolai L, Leunig A, Brambs S, Kaiser R, Weinberger T, Weigand M, et al. Immunothrombotic dysregulation in COVID-19 pneumonia is associated with respiratory failure and coagulopathy. Circulation. (2020) 142:117689. doi: 10.1161/CIRCULATIONAHA.120.048488

95. Li X, Wang L, Yan S, Yang F, Xiang L, Zhu J, et al. Clinical characteristics of 25 death caseswith COVID-19: a retrospective review of medical records in a single medical center, Wuhan, China. Int J Infect Dis. (2020) 94:12832. doi: 10.1016/j.ijid.2020.03.053

96. Chen T, Wu D, Chen H, Yan W, Yang D, Chen G, et al. Clinical characteristics of 113 deceased patients with coronavirus disease 2019: retrospective study. BMJ (Clin. Res. Ed.). (2020) 368:m1091. doi: 10.1136/bmj.m1091

97. Desai I, Manchanda R, Kumar N, Tiwari A, Kumar M. Neurological manifestations of coronavirus disease 2019: exploring past to understand present. Neurol Sci. (2021) 42:773-85. doi: 10.1007/s10072-020-04964-8

98. Wu Y, Xu X, Chen Z, Duan J, Hashimoto K, Yang L, et al. Nervous system involvement after infection with COVID-19 and other coronaviruses. Brain Behav Immun. (2020) 87:18-22. doi: 10.1016/j.bbi.2020.03.031

99. Mao L, Jin H, Wang M, Hu Y, Chen S, He Q, et al. Neurologic manifestations of hospitalized patients with coronavirus disease 2019 in Wuhan, China. JAMA Neurol. (2020) 77:683-90. doi: 10.1001/jamaneurol.2020. 1127

100. Munz M, Wessendorf S, Koretsis G, Tewald F, Baegi R, Krämer S, et al. Acute transverse myelitis after COVID-19 pneumonia. J Neurol. (2020) 267:2196-7. doi: 10.1007/s00415-020-09934-w
101. Steardo L, Steardo L, Zorec R, Verkhratsky A. Neuroinfection may contribute to pathophysiology and clinical manifestations of COVID-19. Acta Physiol. (2020) 229:e13473. doi: 10.1111/apha.13473

102. Tan YK, Goh C, Leow A, Tambyah PA, Ang A, Yap ES, et al. COVID19 and ischemic stroke: a systematic review and meta-summary of the literature. J. Thromb. Thromb. (2020) 50:587-95. doi: 10.1007/s11239-02002228-y

103. Wang M, Li T, Qiao F, Wang L, Li C, Gong Y. Coronavirus disease 2019 associated with aggressive neurological and mental abnormalities confirmed based on cerebrospinal fluid antibodies: a case report. Case Rep Med (Baltimore). (2020) 99:e21428. doi: 10.1097/MD.0000000000021428

104. Ahmad I, Rathore FA. Neurological manifestations and complications of COVID-19: a literature review. J Clin Neurosci. (2020) 77:8-12. doi: 10.1016/j.jocn.2020.05.017

105. Md Noh MSF. COVID-19 and cerebral hemorrhage: proposed mechanisms. J Neuroradiol. (2021) 45:125-6. doi: 10.1016/j.neurad.2020.05.007

106. Medicherla CB, Pauley RA, de Havenon A, Yaghi S, Ishida K, Torres JL. Cerebral venous sinus thrombosis in the COVID-19 pandemic. J NeuroOphthalmol. (2020) 40:457-62. doi: 10.1097/WNO.0000000000001122

107. Kokou-Kpolou CK, Megalakaki O, Laimou D, Kousouri M. Insomnia during COVID-19 pandemic and lockdown: prevalence, severity, and associated risk factors in French population. Psychiatry Res. (2020) 290:113128. doi: 10.1016/j.psychres.2020.113128

108. Bolay H, Gül A, Baykan B. COVID-19 is a real headache! Headache. 60:141521. doi: $10.1111 /$ head. 13856

109. Sedaghat Z, Karimi N. Guillain Barre syndrome associated with COVID-19 infection: a case report. J Clin Neurosci. (2020) 76:233-5. doi: 10.1016/j.jocn.2020.04.062

110. Guidon AC, Amato AA. COVID-19 and neuromuscular disorders. Neurology. (2020) 94:959-69. doi: 10.1212/WNL.0000000000009566

111. Diezma-Martín AM, Morales-Casado MI, García-Alvarado N, Vadillo Bermejo A, López-Ariztegui N, Sepúlveda Berrocal MA. Tremor and ataxia in COVID-19. Temblor y ataxia en COVID-19. Neurologia. (2020) 35:40910. doi: 10.1016/j.nrl.2020.06.005

112. AlKetbi R, AlNuaimi D, AlMulla M, AlTalai N, Samir M, Kumar $\mathrm{N}$, et al. Acute myelitis as a neurological complication of Covid19: a case report and MRI findings. Rad Case Rep. (2020) 15:15915. doi: 10.1016/j.radcr.2020.06.001

113. Vindegaard N, Benros ME. COVID-19 pandemic and mental health consequences: systematic review of the current evidence. Brain Behav Immun. (2020) 89:531-42. doi: 10.1016/j.bbi.2020.05.048

114. Rentero D, Juanes A, Losada CP, Álvarez S, Parra A, Santana V, Martí I, et al. New-onset psychosis in COVID-19 pandemic: a case series in Madrid. Psychiatry Res. (2020) 290:113097. doi: 10.1016/j.psychres.2020.113097

115. Wang C, Pan R, Wan X, Tan Y, Xu L, Ho CS, et al. Immediate psychological responses and associated factors during the initial stage of the 2019 coronavirus disease (COVID-19) epidemic among the general population in China. Int J Environ Res Public Health. (2020) 17:1729. doi: 10.3390/ijerph17051729

116. Chua SE, Cheung V, McAlonan GM, Cheung C, Wong JW, Cheung EP, et al. Stress and psychological impact on SARS patients during the outbreak. Can J Psychiatry. (2004) 49:385-90. doi: 10.1177/070674370404900607

117. Radzikowska U, Ding M, Tan G, Zhakparov D, Peng Y, Wawrzyniak P, et al. Distribution of ACE2, CD147, CD26, and other SARS-CoV-2 associated molecules in tissues and immune cells in health and in asthma, COPD. obesity, hypertension, and COVID-19 risk factors. Allergy. (2020) 75:282945. doi: 10.1111/all.14429

118. Sachdeva M, Gianotti R, Shah M, Bradanini L, Tosi D, Veraldi $\mathrm{S}$, et al. Cutaneous manifestations of COVID-19: report of three cases and a review of literature. J Dermatol Sci. (2020) 98:75-81. doi: 10.1016/j.jdermsci.2020.04.011

119. Joob B, Wiwanitkit V. COVID-19 can present with a rash and be mistaken for dengue. J Am Acad Dermatol. (2020) 82:e177. doi: 10.1016/j.jaad.2020.03.036

120. Salido M, Joven B, D'Cruz DP, Khamashta MA, Hughes GRV. Increased cutaneous reactions to hydroxychloroquine (Plaquenil) possibly associated with formulation change: comment on the letter by Alarcon. Arthritis Rheum. (2002) 46:3392-6. doi: 10.1002/art.10565 
121. Jamiolkowski D, Muhleisen B, Muller S, Navarini AA, Tzankov A, Roider E. SARS-CoV-2 PCR testing of skin for COVID-19 diagnostics: a case report. Lancet. (2020) 396:598-9. doi: 10.1016/S0140-6736(20)31754-2

122. Recalcati S. Cutaneous manifestations in COVID-19: a first perspective. J Eur Acad Dermatol Venereol. (2020) 34:e212-3. doi: 10.1111/jdv.16387

123. Tammaro A, Adebanjo GAR, Parisella FR, Pezzuto A, Rello J. Cutaneous manifestations in COVID-19: the experiences of Barcelona and Rome. J Eur Acad Dermatol Venereol. (2020) 34:e306-7. doi: 10.1111/jdv.16530

124. Zhang X, Chen X, Chen L, Deng C, Zou X, Liu W, et al. The evidence of SARS-CoV-2 infection on ocular surface. Ocul Surf. (2020) 18:3602. doi: 10.1016/j.jtos.2020.03.010

125. Wu P, Duan F, Luo C, Liu Q, Qu X, Liang L, et al. Characteristics of ocular findings of patients with coronavirus disease (2019). (COVID19) in Hubei province, China. JAMA Ophthalmol. (2020) 138:5758. doi: 10.1001/jamaophthalmol.2020.1291

126. Hu Y, Chen T, Liu M, Zhang L, Wang F, Zhao S, et al. Positive detection of SARS-CoV-2 combined HSV1 and HHV6B virus nucleic acid in tear and conjunctival secretions of a non-conjunctivitis COVID-19 patient with obstruction of common lacrimal duct. Acta Ophthalmol. (2020) 98:85963. doi: 10.1111/aos.14456

127. Kaya H, Çalişkan A, Okul M, Sari T, Akbudak IH. Detection of SARS-CoV-2 in the tears and conjunctival secretions of coronavirus disease 2019 patients. J Infect Dev Ctries. (2020) 14:977-81. doi: 10.3855/jidc.13224

128. Torres-Costa S, Lima-Fontes M, Falcão-Reis F, Falcão M. SARS-COV-2 in ophthalmology: current evidence and standards for clinical practice. Acta Med Port. (2020) 33:593-600. doi: 10.20344/amp.14118

129. Chen M, Zhou W, Xu W. Thyroid function analysis in 50 patients with COVID-19: a retrospective study. Thyroid. (2021) 31:8-11. doi: 10.1089/thy.2020.0363

130. Li, J, Wang X, Chen J, Zuo X, Zhang H, Deng A. COVID-19 infection may cause ketosis and ketoacidosis. Diabetes Obes Metab. (2020) 22:193541. doi: 10.1111/dom.14057

131. Gentile S, Strollo F, Mambro A, Ceriello A. COVID-19, ketoacidosis and new-onset diabetes: are there possible cause and effect relationships among them? Diabetes Obes Metab. (2020) 22:2507-8. doi: 10.1111/dom. 14170

132. Mukherjee R, Smith A, Sutton R. Covid-19-related pancreatic injury. $\mathrm{Br} \mathrm{J}$ Surg. (2020) 107:e190. doi: 10.1002/bjs.11645

133. Chatterjee S, Ghosh R, Biswas P, Dubey S, Guria RT, Sharma CB, et al. COVID-19: the endocrine opportunity in a pandemic. Minerva Endocrinol. (2020) 45:204-27. doi: 10.23736/S0391-1977.20.03216-2

134. Almeida MQ, Mendonca BB. Adrenal insufficiency and glucocorticoid use during the COVID-19 pandemic. Clin S Paulo Brazil. (2020) 75:e2022. doi: 10.6061/clinics/2020/e2022

135. Pal R. COVID-19, hypothalamo-pituitary-adrenal axis and clinical implications. Endocrine. (2020) 68:251-2. doi: 10.1007/s12020-020-02325-1

136. Okçelik S. COVID-19 pneumonia causes lower testosterone levels. Andrologia. (2020) 53:e13909. doi: 10.1111/and.13909

137. Yang M, Chen S, Huang B, Zhong JM, Su H, Chen YJ, et al. Pathological findings in the testes of COVID-19 patients: clinical implications. Eur Urol Focus. (2020) 6:1124-9. doi: 10.1016/j.euf.2020.05.009

138. Wang Z, Xu X. scRNA-seq profiling of human testes reveals the presence of the ACE2 receptor, a target for SARS-CoV-2 infection in spermatogonia, leydig and sertoli cells. Cells. (2020) 9:920. doi: 10.3390/cells9040920

139. Bornstein SR, Rutkowski H, Vrezas I. Cytokines and steroidogenesis. Mol Cell Endocrinol. (2004) 215:135-41. doi: 10.1016/j.mce.2003. 11.022

140. Mahyuddin AP, Kanneganti A, Wong JJL, Dimri PS, Su LL, Biswas A, et al. Mechanisms and evidence of vertical transmission of infections in pregnancy including SARS-CoV-2s. Prenat Diagn. (2020) 40:165570. doi: $10.1002 /$ pd.5765

141. Sheth S, Shah N, Bhandari V. Outcomes in COVID-19 positive neonates and possibility of viral vertical transmission: a narrative review. Am J Perinatol. (2020) 37:1208-16. doi: 10.1055/s-0040-1714719

142. Shanes ED, Mithal LB, Otero S, Azad HA, Miller ES, Goldstein JA. Placental pathology in COVID-19. Am J Clin Pathol. (2020) 154:2332. doi: 10.1093/ajcp/aqaa089
143. Wenling Y, Junchao Q, Xiao Z, Ouyang S. Pregnancy and COVID19: management and challenges. Rev Inst Med Trop S Paulo. (2020) 62:e62. doi: 10.1590/s1678-9946202062062

144. Chi J, Gong W, Gao Q. December 1. Clinical characteristics and outcomes of pregnant women with COVID-19 and the risk of vertical transmission: a systematic review. Arch Gynecol Obstet. (2021) 303:33745. doi: 10.1007/s00404-020-05889-5

145. Nägele MP, Haubner B, Tanner FC, Ruschitzka F, Flammer AJ. Endothelial dysfunction in COVID-19: current findings and therapeutic implications. Atherosclerosis. (2020) 314:58-62. doi: 10.1016/j.atherosclerosis.2020.10.014

146. Stoneham SM, Milne KM, Nuttall E, Frew GH, Sturrock BR, Sivaloganathan $\mathrm{H}$, et al. Thrombotic risk in COVID-19: a case series and case-control study. Clin Med (Lond., (England). (2020) 20:e76-81. doi: 10.7861/clinmed.2020-0228

147. Middeldorp S, Coppens M, van Haaps TF, Foppen M, Vlaar AP, Müller MCA, et al. Incidence of venous thromboembolism in hospitalized patients with COVID-19. J Thromb Haemost. (2020) 18:1995-2002. doi: 10.1111/jth.14888

148. Seitz R, Schramm W. DIC in COVID-19: implications for prognosis and treatment? J Thromb Haemost. (2020) 18:1798-9. doi: 10.1111/jth.14878

149. Zhao X, Wang K, Zuo P, Liu Y, Zhang M, Xie S, et al. Early decrease in blood platelet count is associated with poor prognosis in COVID-19 patientsindications for predictive, preventive, and personalized medical approach. EPMA J. (2020) 11:1-7. doi: 10.1007/s13167-020-00208-Z

150. Bao C, Tao X, Cui W, Yi B, Pan T, Young KH, et al. SARS-CoV2 induced thrombocytopenia as an important biomarker significantly correlated with abnormal coagulation function, increased intravascular blood clot risk and mortality in COVID-19 patients. Exp Hematol Oncol. (2020) 9:16. doi: 10.1186/s40164-020-00172-4

151. Pourbagheri-Sigaroodi A, Bashash D, Fateh F, Abolghasemi H. Laboratory findings in COVID-19 diagnosis and prognosis. Clin Chim Acta Int J Clin Chem. (2020) 510:475-82. doi: 10.1016/j.cca.2020.08.019

152. Wang D, Hu B, Hu C, Zhu F, Liu X, Zhang J, et al. Clinical characteristics of 138 hospitalized patients with 2019 novel coronavirus-infected pneumonia in Wuhan, China. JAMA. (2020) 323:1061-9. doi: 10.1001/jama.2020.1585

153. Han H, Yang L, Liu R, Liu F, Wu KL, Li J, et al. Prominent changes in blood coagulation of patients with SARS-CoV-2 infection. Clin Chem Lab Med. (2020) 58:1116-20. doi: 10.1515/cclm-2020-0188

154. Tang N, Bai H, Chen X, Gong J, Li D, Sun Z. Anticoagulant treatment is associated with decreased mortality in severe coronavirus disease 2019 patients with coagulopathy. J Thromb Haemost. (2020) 18:10949. doi: $10.1111 /$ jth.14817

155. Wu T, Zuo Z, Kang S, Jiang L, Luo X, Xia Z, et al. Multi-organ dysfunction in patients with COVID-19: a systematic review and meta-analysis. Aging Dis. (2020) 11:874-94. doi: 10.14336/AD.2020.0520

156. Toprak Celenay S, Karaaslan Y, Mete O, Ozer Kaya D. Coronaphobia, musculoskeletal pain, and sleep quality in stayat home and continued-working persons during the 3-month Covid-19 pandemic lockdown in Turkey. Chronobiol Int. (2020) 37:1778-85. doi: 10.1080/07420528.2020.1815759

157. Paliwal VK, Garg RK, Gupta A, Tejan N. Neuromuscular presentations in patients with COVID-19. Neurol. Sci. (2020) 41:3039-56. doi: 10.1007/s10072-020-04708-8

158. Disser NP, De Micheli AJ, Schonk MM, Konnaris MA, Piacentini AN, Edon DL, et al. Musculoskeletal consequences of COVID-19. J Bone Joint Surg Am Volume. (2020) 102:1197-204. doi: 10.2106/JBJS.20.00847

159. Beydon M, Chevalier K, Al Tabaa O, Hamroun S, Delettre AS, Thomas M, et al. Myositis as a manifestation of SARS-CoV-2. Ann Rheum Dis. (2020). doi: 10.1136/annrheumdis-2020-217573. [Epub ahead of print].

160. CDC. Symptoms of Coronavirus. CDC (2020). Available online at: https:// www.cdc.gov/coronavirus/2019-ncov/symptoms-testing/symptoms.html (accessed June 26, 2020).

161. CDC. Coronavirus Disease (2019). (COVID-19): Evaluating and Testing PUI. Centers for Disease Control and Prevention (2020). Available online at: https://www.cdc.gov/coronavirus/2019-ncov/hcp/clinical-guidancemanagement-patients.html (accessed June 9, 2020).

162. CDC. Interim Clinical Guidance for Management of Patients With Confirmed Coronavirus Disease (COVID-19). CDC (2020). Available online at: https:// 
www.cdc.gov/coronavirus/2019-ncov/hcp/clinical-guidance-managementpatients.html (accessed June 9, 2020)

163. Gousseff M, Penot P, Gallay L, Batisse D, Benech N, Bouiller K, et al. Clinical recurrences of COVID-19 symptoms after recovery: viral relapse, reinfection or inflammatory rebound? J Infect. (2020) 81:81646. doi: $10.1016 /$ j.jinf.2020.06.073

164. Infectious Diseases Society of America. COVID-19 Prioritization of Diagnostic Testing (2020). Available online at: https://www.idsociety.org/ globalassets/idsa/public-health/covid-19-prioritization-of-dx-testing.pdf (accessed March 24, 2020).

165. CR. ACR Recommendations for the Use of Chest Radiography and Computed Tomography (CT) for Suspected COVID-19 Infection. American College of Radiology (2020). Available online at: https://www.acr.org/Advocacyand-Economics/ACR-Position-Statements/Recommendations-for-ChestRadiography-and-CT-for-Suspected-COVID19-Infection (accessed April 2, 2020).

166. Wang Y, Liu Y, Liu L, Wang X, Luo N, Ling L. Clinical outcome of 55 asymptomatic cases at the time of hospital admission infected with SARS-Coronavirus-2 in Shenzhen, China. J Infect Dis. (2020) 221:17704. doi: 10.1093/infdis/jiaal19

167. Bogoch II, Watts A, Thomas-Bachli A, Huber C, Kraemer MUG, Khan K. January 14. Pneumonia of unknown etiology in Wuhan, China: potential for international spread via commercial air travel. J Travel Med. (2020) 27:2. doi: $10.1093 / \mathrm{jtm} / \mathrm{taaa} 008$

168. Li M, Lei P, Zeng B, Li Z, Yu P, Fan B, et al. March 20. Coronavirus disease (COVID-19): spectrum of CT findings and temporal progression of the disease. Acad Radiol. (2020) 27:603-8. doi: 10.1016/j.acra.2020.03.003

169. CDC. COVID-19 Response Team. Coronavirus disease 2019 in children - United States. MMWR Morb Mortal Wkly Rep. (2020) 69:4226. doi: 10.15585/mmwr.mm6914

170. Lu X, Zhang L, Du H, Zhang J, Li YY, Qu J, et al. SARS-CoV-2 infection in children. N Engl J Med. (2020) 382:1663-5. doi: 10.1056/NEJMc2005073

171. Castagnoli R, Votto M, Licari A, Brambilla I, Bruno R, Perlini S, et al. Severe acute respiratory syndrome coronavirus 2 (SARS-CoV-2) infection in children and adolescents: a systematic review. JAMA Pediatr. (2020) 174:882-9. doi: 10.1001/jamapediatrics.2020.1467

172. Foust AM, Phillips GS, Chu WC, Daltro P, Das KM, Garcia-Peña P, et al. International expert consensus statement on chest imaging in pediatric COVID-19 patient management: imaging findings, imaging study reporting and imaging study recommendations. Rad Cardiothorac Imaging. (2020) 2:e200214. doi: 10.1148/ryct.2020200214

173. Pinheiro DS, Santos RS, Jardim PCBV, Silva EG, Reis AAS, Pedrino GR, et al. The combination of ACE I/D and ACE2 G8790A polymorphisms revels susceptibility to hypertension: a genetic association study in Brazilian patients. PLoS ONE. (2019) 14:e0221248. doi: 10.1371/journal.pone.0221248

174. Wu YH, Li JY, Wang C, Zhang LM, Qiao H. The ACE2 G8790A polymorphism: involvement in type 2 diabetes mellitus combined with cerebral stroke. J Clin Lab Anal. (2017) 31:2. doi: 10.1002/jcla. 22033

175. Yang M, Zhao J, Xing L, Shi L. The association between angiotensinconverting enzyme 2 polymorphisms and essential hypertension risk: a meta-analysis involving 14,122 patients. J Renin Angiotensin Aldosterone Syst. (2015) 16:1240-4. doi: 10.1177/14703203145 49221

176. Gemmati D, Tisato V. Genetic hypothesis and pharmacogenetics side of renin-angiotensin-system in COVID-19. Genes (Basel). (2020) 11:1044. doi: 10.3390/genes11091044

177. Fan Q, Zhang W, Li B, Li DJ, Zhang J, Zhao F. Association between $\mathrm{ABO}$ blood group system and COVID-19 susceptibility in Wuhan. Front Cell Infect Microbiol. (2020) 10:404. doi: 10.3389/fcimb.2020. 00404

178. Gérard C, Maggipinto G, Minon JM. COVID-19 and ABO blood group: another viewpoint. Br J Haematol. (2020) 190:e93-4. doi: 10.1111/bjh.16884

179. Yao X, Ye F, Zhang M, Cui C, Huang B, Niu P, et al. In vitro antiviral activity and projection of optimized dosing design of hydroxychloroquine for the treatment of severe acute respiratory syndrome coronavirus 2 (SARS-CoV2). Clin Infect Dis. (2020) 71:732-9. doi: 10.1093/cid/ciaa237
180. CDC. Clinical Care Guidance for Healthcare Professionals About Coronavirus (COVID-19). CDC (2020). Available online at: https://www.cdc.gov/ coronavirus/2019-ncov/hcp/clinical-care.html (accessed June 9, 2020).

181. McCreary EK, Pogue JM. COVID-19 treatment: a review of early and emerging options. Open Forum Infect Dis. (2020) 7:ofaa105. doi: 10.1093/ofid/ofaa105

182. Bhimraj A, Morgan RL, Shumaker AH, Lavergne V, Baden L, Cheng VC, et al. Infectious diseases society of america guidelines on the treatment and management of patients with COVID-19. Clin Infect Dis. (2020). doi: 10.1093/cid/ciaa478. [Epub ahead of print].

183. FDA. FDA Approves First Treatment for COVID-19. FDA Gov (2020). Available online at: https://www.fda.gov/news-events/pressannouncements/fda-approves-first-treatment-covid-19 (accessed October 22, 2010).

184. FDA News Release. FDA Reissues Emergency Use Authorization for Convalescent Plasma. Food US, and Drug Administration (2020). Available online at: https://www.fda.gov/media/141477/download (accessed December 8, 2020).

185. FDA. Fact Sheet for Healthcare Providers Emergency Use Authorization (EUA) of Baricitinib (2020). Available online at: fda.gov. Available online: https://www.fda.gov/media/143823/download (accessed November 19, 2020).

186. Zhou P, Yang XL, Wang XG, Hu B, Zhang L, Zhang W, et al. A pneumonia outbreak associated with a new coronavirus of probable bat origin. Nature. (2020) 579:270-3. doi: 10.1038/s41586-020-2012-7

187. Medscape Med. News. First Randomized Trial Reassures on ACEIs, ARBs in COVID-19. (2020). Available online at: https://www.medscape.com/ viewarticle/936666

188. Wang M, Cao R, Zhang L, Yang X, Liu J, Xu M, et al. Remdesivir and chloroquine effectively inhibit the recently emerged novel coronavirus (2019-nCoV) in vitro. Cell Res. (2020) 30:269-71. doi: 10.1038/s41422-020-0282-0

189. Lopez A, Duclos G, Pastene B, Bezulier K, Guilhaumou R, Solas C, et al. Effects of hydroxychloroquine on Covid-19 in Intensive Care Unit patients: preliminary results. Int $J$ Antimicrob Agents. (2020) 56:106136. doi: 10.1016/j.ijantimicag.2020. 106136

190. Ferguson J, Volk S, Vondracek T, Flanigan J, Chernaik A. September 3. Empiric therapeutic anticoagulation and mortality in critically ill patients with respiratory failure from SARS-CoV-2: a retrospective cohort study. J Clin Pharmacol. (2020) 60:1411-5. doi: 10.1002/jcph. 1749

191. Paranjpe I, Fuster V, Lala A, Russak AJ, Glicksberg BS, Levin MA, et al. Association of treatment dose anticoagulation with in-hospital survival among hospitalized patients with COVID-19. J Am Coll Cardiol. (2020) 76:122-4. doi: 10.1016/j.jacc.2020.05.001

192. Muniyappa R, Gubbi S. March 31. COVID-19 pandemic, corona viruses, diabetes mellitus. Am J Physiol Endocrinol Metab. (2020) 318:E73641. doi: 10.1152/ajpendo.00124.2020

193. DPP4 Dipeptidyl Peptidase 4. Natl Cent. Biotechnol. Inf. (NCBI). (2020). Available online at: https://www.ncbi.nlm.nih.gov/gene/1803 (accessed April 21, 2020).

194. RECOVERY Collaborative Group, Horby P, Lim WS, Emberson JR, Mafham M, Bell JL, et al. Dexamethasone in hospitalized patients with Covid-19 - preliminary. $N$ Engl J Med. (2021) 384:693-704. doi: 10.1056/NEJMoa2021436

195. Alhazzani W, Møller MH, Arabi YM, Loeb M, Gong MN, Fan E, et al. Surviving sepsis campaign: guidelines on the management of critically ill adults with coronavirus Disease (2019). (COVID-19). Crit Care Med. (2020) 48:e440-69. doi: 10.1097/CCM.00000000000 04363

196. Guideline WHO. Corticosteroids for COVID-19 - Living Guidance. World Health Organization (2020). Available online at: https://www.who.int/ publications/i/item/WHO-2019-nCoV-Corticosteroids-2020.1 (accessed Sepetmber 3, 2020).

197. I-SPY COVID-19 TRIAL: an adaptive platform trial for critically ill patients (I-SPY_COVID) (2020). Clin. Trials.gov. Available online at: 
https://clinicaltrials.gov/ct2/show/NCT04488081 (accessed August 25, 2020).

198. Adaptive COVID-19 treatment Trial 3 ACTT-3 (2020). Clin. Trials.gov. Available online at: https://clinicaltrials.gov/ct2/show/NCT04492475 (accessed August 7, 2020).

199. Yao JS, Paguio JA, Dee EC, Tan HC, Moulick A, Milazzo C, et al. The minimal effect of zinc on the survival of hospitalized patients with Covid-19: an observational study. Chest. (2021) 159:108-11. doi: 10.1016/j.chest.2020. 06.082

200. Meltzer DO, Best TJ, Zhang H, Vokes T, Arora V, Solway J. Association of vitamin D status and other clinical characteristics with COVID-19 test results. JAMA Netw Open. (2020) 3:e2019722. doi: 10.1001/jamanetworkopen.2020.19722

201. MediciNova. MediciNova Announces Opening of Investigational New Drug Application for MN-166 (ibudilast) for Prevention of Acute Respiratory Distress Syndrome in Patients with COVID-19 (2020). Available online at: https://investors.medicinova.com/news-releases/news-release-details/ medicinova-announces-opening-investigational-new-drug-1/

202. Gautret P, Lagier JC, Parola P, Hoang VT, Meddeb SJ, Sevestre J, et al. Hydroxychloroquine-Azithromycin and COVID-19 (2020). Available online at: https://www.mediterranee-infection.com/wp-content/uploads/2020/03/ COVID-IHU-2-1.pdf
203. Skipper CP, Pastick KA, Engen NW, Bangdiwala AS, Abassi M, Lofgren $\mathrm{SM}$, et al. Hydroxychloroquine in nonhospitalized adults with early COVID-19: a randomized trial. Ann Intern Med. (2020) 173:62331. doi: 10.7326/M20-4207

Conflict of Interest: The authors declare that the research was conducted in the absence of any commercial or financial relationships that could be construed as a potential conflict of interest.

Publisher's Note: All claims expressed in this article are solely those of the authors and do not necessarily represent those of their affiliated organizations, or those of the publisher, the editors and the reviewers. Any product that may be evaluated in this article, or claim that may be made by its manufacturer, is not guaranteed or endorsed by the publisher.

Copyright $\odot 2021$ Elrobaa and New. This is an open-access article distributed under the terms of the Creative Commons Attribution License (CC BY). The use, distribution or reproduction in other forums is permitted, provided the original author(s) and the copyright owner(s) are credited and that the original publication in this journal is cited, in accordance with accepted academic practice. No use, distribution or reproduction is permitted which does not comply with these terms. 